\title{
Molecular fossils and other organic markers as palaeoenvironmental indicators of the Messinian Calcare di Base Formation: normal versus stressed marine deposition (Rossano Basin, northern Calabria, Italy)
}

\author{
Adriano Guido $^{a}$, Jérémy Jacob ${ }^{b}$, Pascale Gautret ${ }^{b}$, Fatima Laggoun-Défarge ${ }^{b}$, Adelaide \\ Mastandrea $^{\mathrm{a}}$ and Franco Russo ${ }^{\mathrm{a}}$, \\ ${ }^{a}$ Dipartimento di Scienze della Terra, Università della Calabria, Via Bucci Cubo 15b I-87036 \\ Rende (CS), Italy \\ bISTO, UMR 6113 du CNRS - Université d'Orléans, Bâtiment Géosciences, 45067 Orléans, \\ France
}

\begin{abstract}
A multidisciplinary study has been carried out on the Late Miocene (Messinian) Calcare di Base Formation in northern Calabria, Italy, with the aim of understanding the depositional conditions of these enigmatic carbonate sediments that have been interpreted as evaporitic or diagenetic limestone. The research has been developed through sedimentological (microfacies), organic petrography and geochemical analyses (palynofacies, Rock-Eval pyrolysis and gas chromatography/mass spectrometry). The carbonates studied preserve their original mineralogy (aragonite) and microstructure.
\end{abstract}

The prevailing microfacies consists of clotted peloidal micrite with antigravitative fabric. Larger and darker cylindrical-subcylindrical micritic grains, attributable to faecal pellets, are more or less randomly dispersed in the peloidal micrite. The faecal pellets have been ascribed to copepods because zooclasts of these arthropods were observed in the palynofacies. Bright epifluorescence characterizes the faecal pellets and peloidal micrite, indicating their high content of organic matter. Detrital and stromatolitic microfacies occur rarely (around a few percent). The detrital microfacies is characterized by silt-sized grains organized in thin, sometimes bioturbated, graded laminae. The stromatolitic microfacies shows planar to gently curved/wrinkled laminae organized in dark and light couplets.

The associated sedimentary organic matter shows low maturity, and preserves the original signatures of the source organisms. Rock-Eval pyrolysis revealed a transitional composition between Type II and Type III kerogen, suggesting a mixture of marine and terrigenous organic matter input. The molecular biogeochemical data indicate three main biological signatures: algae, bacteria and higher plants. Organic markers together with sedimentary evidence indicate a marine depositional scenario influenced by freshwater input rather than evaporitic concentration.

We conclude that the most probable bacterial process involved in carbonate precipitation of the Calcare di Base, considering the freshwater input and consequent probable enrichment in organic matter and $\mathrm{Ca}^{2+}$ ions, is ammonification of amino-acids in aerobic conditions. 
Keywords: Microfacies; Organic matter; Depositional environment; Calcare di Base Formation; Messinian; Calabria; Italy

\section{Introduction}

During the Messinian, the Mediterranean area was affected by one of the greatest evaporitic events in Earth history: the Messinian Salinity Crisis. This occurred in a complex palaeogeographic environment, inherited from a highly diversified geodynamic context, and was geologically relatively short, 640 kyr ([Krijgsman et al., 1999a] and [Krijgsman et al., 1999b]). The environmental changes relating to the Messinian Salinity Crisis are still intensely debated. An exhaustive and thorough review of the depositional environments and mechanisms involved is provided by Rouchy and Caruso (2006).

In southern Italy (Sicily and Calabria), transition from marine to evaporitic conditions is documented by a succession of diverse sedimentary deposits, including marls and diatomites (Tripoli Formation), transitional carbonates (Calcare di Base Formation), and evaporites (Gessoso Solfifera Formation). Interpretation of the Calcare di Base is complicated by absence of macrobiota and diagnostic sedimentological structures.

The depositional conditions of the Calcare di Base are still an open question ([McKenzie, 1985], [Bellanca and Neri, 1986], [Decima et al., 1988], [Rouchy and Saint-Martin, 1992], [Pedley and Grasso, 1993], [Bellanca et al., 2001] and [Rouchy and Caruso, 2006]) and not all the researchers agree with the hypothesis that these carbonates represent the actual onset of the Salinity Crisis (Rouchy and Caruso, 2006). A comprehensive geological description of the Calcare di Base was carried out by Ogniben (1957) who later described the lithologies in detail and gave an open interpretation of the depositional environments (Ogniben, 1963). Tamajo (1961) recognized for the first time traces of organic elements within these carbonate beds. Many authors ([McKenzie, 1985], [Bellanca and Neri, 1986], [Decima et al., 1988], [Rouchy and Saint-Martin, 1992], [Pedley and Grasso, 1993] and [Bellanca et al., 2001]) have maintained that in Sicily the Calcare di Base was deposited in a sedimentary environment characterized by evaporitic conditions in which sulphate reducing bacteria diagenetically replaced Ca-sulphate by carbonate. They support this interpretation mainly from the presence in the carbonate sediments of moulds and pseudomorphs after gypsum and halite, sulphur deposits, and very low $\delta^{13} \mathrm{C}$ isotopic signals.

In the Rossano Basin, the Calcare di Base is massive, without any evidence of evaporitic minerals, and is preserved as aragonite. To characterize these carbonate sediments we used a new approach: analysis of the sedimentary organic matter. This involved palynofacies observations, Rock-Eval pyrolysis analysis, and molecular fossils (biomarkers) characterization. This methodology allows identification of organisms that are otherwise unrecognizable or not preserved and which may have induced biomineralization processes or may be indicative of palaeoecological conditions.

The aim of this paper is to clarify the depositional conditions under which the Calcare di Base formed, including the physicochemical properties of the water column and the possible roles of microbes in the mineralization processes. 


\section{Geological setting}

The Neogene successions of northern Calabria record the sedimentary response to the tectonic evolution of the Calabrian-Arc orogenic system, that experienced abrupt uplift and rapid migration towards the south-east. This caused general accretionary tectonics along the Ionian border, and extensional tectonics in the incipient Tyrrhenian Sea back-arc region. The Rossano basins, along the onshore Ionian side of Calabrian Arc, are interpreted as forearc basins ([Malinverno and Ryan, 1986], [Patacca and Scandone, 1989], [Patacca et al., 1990], [Sartori, 1990], [Cavazza and De Celles, 1993], [Cavazza et al., 1997], [Funiciello et al., 1997], [Critelli, 1999], [Van Dijk et al., 2000], [Bonardi et al., 2001], [Mattei et al., 2002] and [Zecchin et al., 2004]).

The Rossano Basin infill consists of a continental-marine-paralic succession (Roda, 1964). The first depositional unit, Tortonian-early Messinian in age, unconformably overlies earlier deposits and is composed of a transgressive system that rapidly evolved from continental (alluvial conglomerate) to deep marine sedimentation (turbiditic sandstones and pelagic clays). Marls and diatomaceous shales (Tripoli Formation) and fine-grained carbonates (Calcare di Base Formation) cap the unit. The Messinian evaporite unit (Gessoso-Solfifera Formation) composed of gypsum, halite, marls and detrital evaporites, unconformably covers previous deposits. In the Early Pliocene, deep-marine marls and turbiditic sandstones record the restoration of normal marine condition (Zecchin et al., 2004). The Calcare di Base Formation studied here crops out in the Rossano Basin (Fig. 1).

\section{Methods}

\subsection{Sample selection}

The samples were collected from an outcrop near Cropalati village (Fig. 1), selected according to their position in the stratigraphic succession and the features observed in the field (Fig. 2). Six samples were extracted from diatomitic and marly layers of the Tripoli Formation. Only the topmost diatomitic (TR5) and marly (TR6) layers were selected for organic matter investigation. The Tripoli is overlain by the Calcare di Base succession that consists of two metric massive white to yellow fine grained calcareous beds, interbedded with decimetric light-brown laminated marls (Fig. 2). Three samples were collected in each carbonate bed, labelled $\mathrm{CB} 1-\mathrm{CB} 2-\mathrm{CB} 3$ and $\mathrm{CB} 4-\mathrm{CB} 5-\mathrm{CB} 6$, from the bottom to the top, respectively (Fig. 3). Silty sediments (CB1S), filling small cavities of sample CB1, were isolated (Fig. 3). Sample CB4 is composed of two microfacies: stromatolitic (CB4M) and detritic (CB4D). Finally, sample CBM consists of light-brown laminated marls interbedded with massive calcareous layers (Fig. 3).

\subsection{Carbonate characterization}

Carbonate characterization was performed through optical and scanning electron microscope (SEM) microfacies observations, and energy-dispersive X-ray spectrometer (EDS) microanalysis. Chemical composition was determined using a FEI-Philips ESEM-FEG Quanta 200F scanning electron microscope linked to an EDAX Genesis 4000 EDS. The analysed samples were polished with $0.25 \mu \mathrm{m}$ diamond-impregnated surfaces, then etched and carbon coated (about $250 \AA$ ). Working conditions and detector constants were as follows: voltage $15 \mathrm{kV}$, tilt angle $0^{\circ}$, take-off angle $36.01^{\circ}$. 
Uncovered thin-sections were checked for fluorescence to reveal the distribution of the organic matter (OM) ([Dravis and Yurewicz, 1985], [Machel et al., 1991], [Neuweiler and Reitner, 1995] and [Russo et al., 1997]). Fluorescence was induced by a $\mathrm{Hg}$ vapour lamp linked to an Axioplan II imaging microscope (Zeiss) equipped with high performance wide bandpass filters (BP 436/10 nm/LP $470 \mathrm{~nm}$ for green light; BP 450-490 nm/LP $520 \mathrm{~nm}$ for yellow light).

\subsection{Palynofacies}

Organic petrography was carried out on the kerogen fraction, isolated from the carbonate and silicate phases of the sediment via hydrochloric and hydrofluoric acid treatments (Durand and Nicaiase, 1980). The analysis involved identification of the different fractions of OM (palynofacies) using transmitted light and fluorescence in optical microscopy. Two to five grams of the pulverized sample were subjected to acid treatment with HCL (36\%), to dissolve the carbonates, and HF (50\%), to remove the silicates. The solid residue was washed with water and the supernatant was removed after centrifugating. The water washings were repeated several times, until a neutral $\mathrm{pH}$ was attained. A few microlitres (300-500 $\mu \mathrm{l})$ of residue were used for the first series of sections labelled TS (total slide). The remainder was treated with $\mathrm{KOH}(10 \%)$ to solubilize the humic matter, and with $\mathrm{HNO}_{3}(63 \%)$ to oxidize the $\mathrm{OM}$ and the potassium salts that formed. After densimetric separation to remove pyrite, a second series of sections, labelled RS (residual slide) was produced. TS were used for observation of total organic residues while RS were used to identify structured OM, specifically the phytoplankton remains.

\subsection{Rock-Eval pyrolysis}

Qualitative and quantitative assessment of sedimentary OM was performed by Rock-Eval T6 pyrolysis ([Espitalié et al., 1977], [Espitalié et al., 1985a], [Espitalié et al., 1985b], [Espitalié et al., 1986] and [Lafargue et al., 1998]). The Rock-Eval parameters used for this study are: (i) Total Organic Carbon (TOC, \%), the quantity of OM present in the sediment; (ii) Hydrogen Index (HI, in mg HC/g TOC), indicating the amount of hydrocarbon (HC) products released

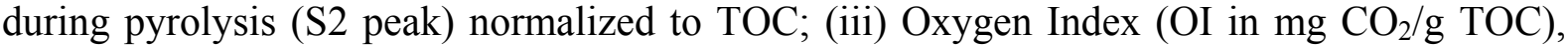
the oxygen content of the $\mathrm{OM}$, calculated from the amounts of $\mathrm{CO}(\mathrm{S} 3 \mathrm{CO})$ and $\mathrm{CO}_{2}\left(\mathrm{~S}_{3} \mathrm{CO}_{2}\right)$ released during pyrolysis, normalized to TOC; (iv) Tmax, the temperature of maximum release of hydrocarbon products during pyrolysis ([Espitalié et al., 1977], [Espitalié et al., 1985a], [Espitalié et al., 1985b] and [Espitalié et al., 1986]) indicates OM maturity in ancient sediments.

Between 50 and $100 \mathrm{mg}$ of dried sediment were used for analysis, depending on the estimated $\mathrm{OM}$ content. The pyrolysis program starts with an isothermal stage of $3 \mathrm{~min}$ at $200^{\circ} \mathrm{C}$. Then the pyrolysis oven temperature is raised at $30^{\circ} \mathrm{C} / \mathrm{min}$ to $650^{\circ} \mathrm{C}$, and held for 3 minutes at this temperature. The oxidation phase, performed in a second oven under an air stream, starts at an isothermal stage at $400{ }^{\circ} \mathrm{C}$, followed by an increase to $850{ }^{\circ} \mathrm{C}$ at $30{ }^{\circ} \mathrm{C} / \mathrm{min}$ and is held at the final temperature for $5 \mathrm{~min}$.

\subsection{Elemental analyses}

Elemental analyses were performed on bulk material with a CNS-2000 LECO ${ }^{\circledR}$ apparatus in order to determine Total Carbon (TC), Nitrogen (N) and sulphur (S) contents. 


\subsection{Lipid biomarkers}

Considering the very low TOC, precautions were taken to avoid contamination either from recent organic material or from industrial contaminants during laboratory treatment. In order to verify the reliability of the data, we compared our results with those reported in the literature for similar sedimentary conditions and/or biological sources ([Bartle et al., 1979], [Tissot and Welte, 1984], [Baranger and Disnar, 1988], [Baranger et al., 1989], [Russell et al., 1997], [Thiel et al., 1997] and [Peters et al., 2005]).

Extractions - Three grams of powdered dry sediments were ultrasonically extracted three times with a mixture of dichloromethane/methanol (1:1). Samples were centrifuged following each extraction and the supernatant was collected. Combined extracts were dried under nitrogen. Because Leco analysis revealed very low sulphur concentrations, only free lipids were analysed, without any desulphurization.

Separations - The acidic fractions were separated from the total extracts by solid phase extraction performed on Pasteur pipettes filled with aminopropyl bonded silica. Neutral compounds were eluted with dichloromethane/methanol (1:1). Acidic compounds were eluted with ether after acidification of the medium with ether:formic acid (9:1). Fatty acids were then esterified using acetyl chloride in anhydrous methanol before analysis. The hydrocarbon fraction was separated from the neutral fraction by flash chromatography on deactivated silica ( $5 \%$ water) by eluting with heptane.

Identifications and quantifications - Due to frequent coelutions and low concentrations, relative quantification of steranes, hopanoids and alkylbenzenes was achieved by GC/MS performed on a TRACE-PolarisGCQ (Thermofinnigan). The temperature program was as follows: temperature held at $40^{\circ} \mathrm{C}$ for $1 \mathrm{~min}$, then increased from 40 to $120^{\circ} \mathrm{C}$ at $30{ }^{\circ} \mathrm{C}$ $\min ^{-1}, 120$ to $300{ }^{\circ} \mathrm{C}$ at $5{ }^{\circ} \mathrm{C} \mathrm{min}{ }^{-1}$ with the final isothermal hold at $300{ }^{\circ} \mathrm{C}$ for $20 \mathrm{~min}$. The mass spectrometer operated in the electron impact (EI) mode at $70 \mathrm{eV}$ ionization energy and scanned from 50 to 650 Dalton. Compounds were identified by comparison with published mass spectra and relative retention times. The relative abundance of steranes, hopanes and alkylbenzenes were estimated by measuring the area of the peaks on the $\mathrm{m} / z 91+105$ (alkylbenzenes), $m / z 215$ or 229 (sterenes), $m / z 217$ (steranes), $m / z 231$ (4-methyl-steranes) and $m / z 191$ (hopanoids) ion-specific chromatograms. Fatty acids, as their methyl esters, $n$ alkanes, phytane and pristane, were quantified by GC/FID using a Autosystem XL (Perkin Elmer). The gas chromatograph was fitted with an Rtx ${ }^{\circledR}-5$ Sil MS capillary column (30 $\mathrm{m} \times 0.25 \mathrm{~mm}$ i.d., $0.25 \mu \mathrm{m}$ film thickness) with $5 \mathrm{~m}$ of guard column. The GC operating conditions were the same as in GC/MS. The sample was injected splitless, with the injector temperature set at $280^{\circ} \mathrm{C}$. Helium was the carrier gas. Squalane was added as an internal standard prior to quantification.

\section{Results and interpretation}

\subsection{Microfacies}

Carbonate samples of the Calcare di Base, collected from the Cropalati section, are made up of micritic peloidal wackestones and subordinately packstones. The prevailing microfacies consists of peloidal micrite $(40 \%-50 \%)$ which is characterized by variably sized irregular peloids forming clots with antigravitative fabric. Generally at the border of clots, where there is less organic matter content as observed in epifluorescence, the micrite underwent aggrading 
diagenesis becoming microsparite (15\%-25\%) with crystal sizes ranging from $5 \mu \mathrm{m}$ to $15 \mu \mathrm{m}$. Larger and darker cylindrical-subcylindrical micritic grains $(50 \mu \mathrm{m}-500 \mu \mathrm{m})$, attributable to faecal pellets, are more or less randomly dispersed in the peloidal micrite (Fig. 4a). The biotic origin of faecal pellets and peloidal micrite is supported also by their bright epifluorescence (Fig. 4b) indicative of high organic matter content ([Dravis and Yurewicz, 1985], [Machel et al., 1991], [Neuweiler and Reitner, 1995] and [Russo et al., 1997]).

SEM observations, at high magnification, revealed two types of faecal pellet: those containing silt-sized inclusions of siliciclastic grains and those with coccolithophorid moulds but without relevant terrigenous component (Fig. 5).

X-ray diffraction on carbonate samples (CB2 and CB5) showed that aragonite constitutes about $90 \%$ of the rock volume. EDS microanalyses, performed on the peloid crystals, revealed a noticeable amount of $\mathrm{Sr}$ (more than 15,000 ppm), supporting their original aragonitic mineralogy.

Detrital and stromatolitic microfacies occur rarely (around a few percent). The detrital microfacies is characterized by silt-sized grains organized in thin, sometimes bioturbated, graded laminae (Fig. 6). The boundary between the detritic and peloidal microfacies is commonly burrowed (Fig. 6). The stromatolitic microfacies shows planar to gently curved/wrinkled laminae organized in dark and light couplets (Fig. 7a). Stromatolitic laminae are strongly fluorescent, indicating a high organic matter content (Fig. 4 and Fig. 7).

\subsection{Rock-Eval pyrolysis}

The Rock-Eval parameters are illustrated in Fig. 8. TOC values are very low and range from $0.06 \%$ to $0.19 \%$ in carbonate samples (CB). They are slightly higher (from $0.24 \%$ to $0.31 \%$ ) in the diatomitic and marly samples (TR) of the Tripoli formation and in the marls (CBM) interbedded with the calcareous layers (Fig. 8). HI values range from 306 to $417 \mathrm{mg} \mathrm{HC/g}$ TOC in CB samples. They are lower (from 38 to $67 \mathrm{mg} \mathrm{HC} / \mathrm{g}$ TOC) in TR and CBM samples. OI values range from 105 to $312 \mathrm{mg} \mathrm{CO} 2 / \mathrm{g}$ TOC.

HI and OI values have been plotted in a pseudo-Van Krevelen diagram (Fig. 9). Although some care must be taken in interpreting Rock-Eval pyrolysis data for samples with low TOC values, the distribution of $\mathrm{CB}$ samples in this diagram shows a transitional composition between Type II and Type III kerogen (Tissot and Welte, 1984). This distribution reveals a mixture of marine and terrigenous OM (Fig. 9). In addition, the diagram shows that HI values decrease while OI values increase upward within each carbonate layer. Low HI values for TR and CBM samples can be attributed to mineral matrix effects (Espitalié et al., 1977).

\subsection{Palynofacies observations}

Palynofacies observations show that the kerogen fractions are extremely low in CB samples and slightly higher in TR and CBM samples (Fig. 10). The low amount of OM does not permit relative quantification of the different fractions. It has only been possible to perform qualitative observations of the main organic fractions and to estimate their relative variations along the section (Fig. 10). 
Palynofacies show two major types of components: amorphous organic matter (amorphous $\mathrm{OM}$ ) and structured organic micro-remains comprising both material of terrestrial origin (lignaceous debris, spores and pollen) and phytoplanktonic residues. Two types of amorphous OM families have been distinguished: dark/altered and yellow/preserved (Fig. 10a,b). The absence of structures in this material makes it difficult to identify its origin and nature. However, these components show bright fluorescence under the microscope, which attests to their high hydrogen content, and are abundant in samples showing high HI values, therefore suggesting an algal and/or bacterial origin.

In addition to these OM families, structured particles of higher plant origin are also present (Fig. 10d). These materials have been divided into two groups. The first comprises translucent or yellowish well-preserved ligno-cellulosic tissues and reddish gelified particles (Fig. 10d,h), which were most likely derived from pedogenic material ([Bourdon et al., 2000] and [Sebag et al., 2006]). The second group consists of small sized opaque debris with tabular or equidimensional shape (Fig. 10c), identified as oxidized woody materials. Some of this debris shows residual botanical structures with opaque cell walls and empty cavities and is identified as burnt woody fragments. Spores, pollen (Fig. 10e) and remains of phytoplanktic organisms (Fig. 10f) are also present.

These organic micro-remains are present in all samples of the section studied, but in different proportions. Samples TR5 and TR6 mainly consist of amorphous OM, various materials of terrestrial origin, and a few recognizable phytoplanktic remains. The terrestrial materials, in the sample TR5, are generally present as oxidized and burnt woody fragments. Sample TR6 shows the same kerogen composition except for larger proportions of amorphous OM and lower amounts of oxidized and burnt materials. Many small tabular siliceous fragments, most probably derived from diatom skeletons, are also present. These fragments are always associated with amorphous OM that could have inhibited HF dissolution.

Calcareous samples show predominance of amorphous OM and common phytoplanktonderived membranes. They contain well preserved fragments of arthropods exoskeletons, attributable to copepods that are the probable producers of most of the faecal pellets (Fig. $10 \mathrm{~g})$.

In general, the terrestrial debris content increases upward in each carbonate layer. The CBM sample shows almost the same composition as that of TR samples, except for a larger contribution from terrestrial organic fractions, mainly represented by reddish gelified particles.

\subsection{Biomarkers}

Among the lipids extracted from the analyzed samples, we investigated fatty acids as well as aliphatic and cyclic hydrocarbons.

\subsubsection{Fatty acids}

A representative example (sample TR5) of fatty acid distribution is illustrated in Fig. 11a. The chromatograms show a series of straight-chain fatty acids, ranging from 14 to 32 carbon atoms. Their distribution shows a strong predominance of even carbon-numbered homologues and is bimodal with a first mode centred at $n \mathrm{C}_{16}$ or $n \mathrm{C}_{18}$ and a second one within the range of long-chain fatty acids. Monounsaturated $n \mathrm{C}_{16}\left(\mathrm{C}_{16: 1}\right)$ and $n \mathrm{C}_{18}$ mono- $\left(n \mathrm{C}_{18: 1}\right)$ and di- 
unsaturated $\left(n \mathrm{C}_{18: 2}\right)$ fatty acids were detected in the acid fraction. Among branched fatty acids, only phytanic acid was detected. Because this compound coelutes with $n \mathrm{C}_{18: 2}$ in our analytical conditions, its presence was certified by GC/MS.

The evolution of biomarker fingerprints is illustrated in Fig. 12. Over linear fatty acids, short chain homologues are the most abundant components in all samples, except in CB1S and $\mathrm{CBM}$ where they are subordinate to the long chain fatty acids (Fig. 12c). The $n \mathrm{C}_{16}$ fatty acid is dominant in the TR samples, while the $n \mathrm{C}_{18}$ fatty acid is more abundant in the CB samples. Both these compounds are nearly the sole fatty acids in samples CB4D and CB4M. The ratio between short chain $(<22)$ and long chain $(>22)$ fatty acids is rather low from the bottom of the section up to CBM sample and then increases in CB4D before decreasing up to the top (Fig. 12d). CB1S and CBM samples display the highest proportions of long-chain fatty acids. Unsaturated fatty acids are significantly abundant in samples CB4 (Fig. 12e). $n \mathrm{C}_{18: 1}$ prevails and is the only unsaturated fatty acid in the sample $\mathrm{CB} 3 . n \mathrm{C}_{18: 2}$ follows in abundance, although its coelution with phytanic acid prevents precise quantification of this compound. $n \mathrm{C}_{16: 1}$ compound is less abundant but was detected in both TR and CB.

\subsubsection{Hydrocarbons}

Hydrocarbons are mainly composed of $n$-alkanes and subordinately of alkylbenzenes, hopanes and steranes. A series of branched alkanes has been detected in the range of long chain $n$ alkanes. Acyclic isoprenoid alkanes, namely pristane and phytane were also detected. The $\mathrm{m} / \mathrm{z}$ $57+71+85+99+113$ ion chromatogram of the aliphatic hydrocarbon fraction of sample TR5 displays a series of $n$-alkanes ranging from $n \mathrm{C}_{16}$ to $n \mathrm{C}_{35}$ (Fig. 11b). The distribution of $n$ alkanes shows a classical bimodal pattern. The first mode ranges from $n \mathrm{C}_{16}$ to $n \mathrm{C}_{20}$ and the second mode ranges from $n \mathrm{C}_{27}$ to $n \mathrm{C}_{31}$. Superimposed on these two modes, another modal distribution maximizes at $n \mathrm{C}_{26}$ and shows no predominance of odd-over even-carbon numbered homologues.

The distribution of $n$-alkanes in TR5 and TR6 samples is dominated by the long-chain oddnumbered homologues associated with the modal distribution centred on $n \mathrm{C}_{26}$ with no odd/even predominance (Fig. 12f). Short-chain $n$-alkanes, ranging from $n \mathrm{C}_{16}$ to $n \mathrm{C}_{22}$, are less abundant. In contrast, short chain $n$-alkanes are more abundant in samples located at the bottom of each carbonate bed (CB1 and CB4D) where $n \mathrm{C}_{18}$ or $n \mathrm{C}_{20} n$-alkanes dominate over $n \mathrm{C}_{16}$ (Fig. 12f). The proportions of short chain $n$-alkanes are lower in samples at the top of each carbonate bed (CB3 and CB6). The relative abundance of odd-numbered long chain $n$ alkanes is greatest in the samples with a significant siliciclastic fraction (CB1S, CB4D), in concurrence with lower proportions of short-chain $n$-alkanes (Fig. 12f). The distribution of $n$ alkanes in sample CB4M is characterized by the sole occurrence of the modal distribution centred at $n \mathrm{C}_{26}$ with no odd/even predominance, i.e. significantly different from the corresponding detritic microfacies (CB4D) that contains long chain odd numbered and short chain $n$-alkanes. Both $\mathrm{CB} 5$ and $\mathrm{CB} 6$ samples also show this modal distribution with no odd/even predominance but centred at $n \mathrm{C}_{29}$.

Isoprenoid hydrocarbons only consist of pristane and phytane in our samples (Fig. 11b). The pristane/phytane ratio $(\mathrm{Pr} / \mathrm{Ph})$ ranges from 0.08 (CB1S) to 1.36 (TR6). Pristane was not detected in CB5 and CB6 samples, avoiding the calculation of $\mathrm{Pr} / \mathrm{Ph}$. $\mathrm{Pr} / \mathrm{Ph}$ values do not show any particular trend and fall between 0 and 1 throughout the section. 
Steranes were detected by GC/MS on the $m / z 215+217+231$ specific ion chromatogram (Fig. 11c) and were identified according to Brassell et al. (1986) and Wolff et al. (1986). The desmethylsterane distributions consist of $\mathrm{C}_{27}, \mathrm{C}_{28}$ and $\mathrm{C}_{29}$ isomers with the $5 \alpha$ configuration. The $5 \beta$ isomers are poorly represented. $4 \alpha$-methyl-and $4 \beta$-methyl-steranes were detected in the $\mathrm{C}_{28}$ to $\mathrm{C}_{30}$ range by using $\mathrm{m} / \mathrm{z} 231$ ion chromatogram. Both isomers are found in roughly equal proportions throughout the section. We did not distinguish between $4 \alpha$-methyl-23,24dimethyl-steranes (dinosteranes) and $4 \beta$-methyl-24-ethyl-steranes for the $\mathrm{C}_{30}$ isomers. No diasteranes were found except for $13 \beta, 17 \alpha$ (20S-20R), and $13 \alpha, 17 \beta$ (20R-20S) $\mathrm{C}_{27}$ diasteranes in $\mathrm{CB} 1$ and $\mathrm{CB} 3$ samples.

$\mathrm{C}_{27}$ homologues are strongly dominant in all samples except CB1S and CBM, where they are subordinated to the $\mathrm{C}_{29}$ and $\mathrm{C}_{30}$ homologues (Fig. 12g). 4-methyl-steranes are well represented in every sample but appear more abundant in carbonates than in marls (Fig. 12h). The four $\mathrm{C}_{27}$ diasteranes were only detected in $\mathrm{CB} 1, \mathrm{CB} 1 \mathrm{~S}$ and $\mathrm{CB} 3$ samples. $\mathrm{C}_{30}$ and $\mathrm{C}_{29}$ steranes are in higher proportions in CB1S and CBM samples.

An example of an $\mathrm{m} / \mathrm{z} 191$ mass chromatogram of the hydrocarbon fraction extracted from sample TR5 illustrates the hopanoid distribution (Fig. 11d). Hopanoids are not abundant, and are even absent in some samples. Both $17 \alpha$ and $17 \beta$ trisnorhopanes $\left(\mathrm{C}_{27}\right)$ were found. $\alpha \beta$ and $\beta \alpha$ isomers were detected for norhopanes $\left(\mathrm{C}_{29}\right)$ and hopanes $\left(\mathrm{C}_{30}\right)$ series whereas only $\alpha \beta$ isomers were detected for homohopanes $\left(\mathrm{C}_{31}\right)$ and bishomohopanes $\left(\mathrm{C}_{32}\right)$. The less stable $\beta \beta$ configuration was detected for the norhopanes and hopanes. Small amounts of an unidentified hopene were found in samples TR5, TR6 and CBM.

The $m / z 91+105$ ion chromatograms reveal a series of compounds characterized by a base peak at $\mathrm{m} / \mathrm{z} 91$ or 105 and molecular ions at $\mathrm{m} / \mathrm{z}$ 232, 246, 260 or 274 (Fig. 11e). Published data allow us to interpret these compounds as alkylbenzene structures (Peters et al., 2005). The alkylbenzenes distribution ranges from $\mathrm{C}_{16}$ to $\mathrm{C}_{20}$ total carbon atoms. Each series with the same molecular ion is constituted by five compounds, i.e. pentyl-alkylbenzene, butylalkylbenzene, propyl-alkylbenzene, ethyl-alkylbenzene and methyl-alkylbenzene (Fig. 11e). The alkylbenzenes with a molecular ion at $m / z 260$ are the most abundant. Within each series, the methyl homologues dominate. Alkylbenzenes are present in significant proportions only in CB4D and CB4M samples.

\section{Discussion}

\subsection{Sources of $\mathrm{OM}$}

Rock-Eval pyrolysis reveals a transitional composition between Type II and Type III kerogen, suggesting a mixture of marine and terrigenous OM. These results are in agreement with palynological observations that support a mixed origin of OM.

These different contributions are also supported by biomarker analyses that reveal three types of origin: algae, bacteria, and land plants. Short chain $n$-alkyl lipids (fatty acids and $n$-alkanes) are generally attributed to autochthonous origin, since they are ubiquitously observed in aquatic organisms, such as bacteria and algae (Cranwell, 1982). The dominance of the $\mathrm{C}_{27}$ steranes also reflects a notable phytoplanktic/zooplanktic contribution to the OM (Volkman, 1986). 4-methyl-steranes are supposedly derived from 4-methyl-24-ethylsterol and dinosterol that are specific biomarkers of dinoflagellates (Summons, 1993), although 4-methyl sterols have also been detected in prymnesiophytes and methanotrophic bacteria (Grice et al., 1998). 
It is worth noting that the dominance of $n \mathrm{C}_{16}$ fatty acid over $n \mathrm{C}_{18}$ fatty acid in TR samples coincides with a notable diatomitic contribution. Conversely, $n \mathrm{C}_{18}$ is dominant over $n \mathrm{C}_{16}$ in $\mathrm{CB}$ samples. The relative abundance of $n \mathrm{C}_{16} v s . n \mathrm{C}_{18}$ fatty acids has been proposed to distinguish between diatomitic and bacterial contributions to sediment ([Volkman et al., 1980a], [Volkman et al., 1980b] and [Russell et al., 1997]). Therefore, $n \mathrm{C}_{16}$ predominance could indicate a diatomitic input whereas $n \mathrm{C}_{18}$ predominance could reflect a stronger bacterial contribution, which is corroborated by higher proportions of short chain unsaturated fatty acids in CB4.

Although hopanoids are not abundant, they also indicate a notable prokaryotic input (Ourisson et al., 1987). The unsaturated fatty acid distribution is characteristic of algae or cyanobacteria ([Chuecas and Riley, 1969] and [Russell et al., 1997]). Such compounds are present in recent sediments from normal marine ([Chuecas and Riley, 1969], [Volkman et al., 1980a], [Volkman et al., 1980b] and [Grimalt and Albaigés, 1990]) to hypersaline environments (Grimalt et al., 1992). A bacterial contribution is also substantiated by the presence of a modal distribution of $n$-alkanes maximizing at $n \mathrm{C}_{26}$ with no odd-even carbon number predominance. This specific distribution of $n$-alkanes has previously been attributed to bacterial or algal origin in similar contexts ([Tissot and Welte, 1984], [Baranger and Disnar, 1988], [Baranger et al., 1989] and [Thiel et al., 1997]). A series of isoalkanes, which is often associated with the modal distribution in $n \mathrm{C}_{26}$, is usually considered as a bacterial signature and strengthen our interpretation ([Brassell et al., 1978], [Bartle et al., 1979], [Chaffee et al., 1986], [Connan et al., 1986], [Baranger and Disnar, 1988] and [Baranger et al., 1989]).

Ligno-cellulosic debris were found in significant amounts throughout the section and attest to a contribution from terrestrial higher plants. This observation is in agreement with the presence of long chain $n$-alkyl lipids (fatty acids and $n$-alkanes) that indicate a higher plant input since these compounds are abundant in epicuticular waxes of vascular plants (Eglinton and Hamilton, 1967).

\subsection{Preservation of $\mathrm{OM}$}

The Rock-Eval pyrolysis data should be interpreted with caution, in view of the low TOC values. Tmax values, around $400{ }^{\circ} \mathrm{C}$, indicate that the $\mathrm{OM}$ suffered little or no thermal stress. The higher Tmax values of TR5, TR6 and CBM samples are due to the low HI that forbids the designation of a maximum temperature of cracking on the S2 peak. The presence of wellpreserved and bright-fluorescent spores, pollen, and other organic debris that did not undergo degradation and oxidation indicates, periods of dysoxic/suboxic bottom conditions. The presence of unsaturated fatty acids is unusual for sediments older than $6 \mathrm{Myr}$. Their occurrence in the Calcare di Base Formation constitutes one of the exceptions already mentioned by Russell et al. (1997). The presence of $\beta \beta$ hopanoids indicates that the sediment suffered very low thermal stress ([Mackenzie et al., 1980] and [Seifert and Moldovan, 1980]). Although $\alpha \beta$ hopanoids were abundant, their presence does not strictly indicate intense diagenesis; in fact these compounds are found in living microbial mats (Thiel et al., 2003) and can be produced by soil bacteria (Rosa-Putra et al., 2001).

\subsection{Depositional conditions}

The clotted peloidal micrite fabric of the Calcare di Base points to a bacterially induced mineralization ([Chafetz, 1986], [Buczynski and Chafetz, 1991], [Kazmierczak et al., 1996] and [Folk and Chafetz, 2000]) which includes autotrophic and heterotrophic pathways 
([Castanier et al., 1999] and [Castanier et al., 2000]). We consider that both pathways contributed to the Calcare di Base precipitation and that heterotrophic processes were by far the more common. The aerobic conditions of the depositional environment suggest the oxygenic photosynthesis among the autotrophic pathways. This type of autotrophic carbonatogenesis is documented in the geological record by stromatolitic microfacies. In our sediments stromatolites represent less than $5 \%$ of the rock volume and confirm that the yield of autotrophic bacterial pathways is much lower than heterotrophic ones (Castanier et al., 1999). In particular, considering the presence of oxygen in the depositional environment, the freshwater inputs (with the consequent enrichment in organic matter and $\mathrm{Ca}^{2+}$ ions), the presumed absence of urea or uric acid (notably for the absence of vertebrates), and the very low amount of sulphates, it is reasonable to suppose that the main bacterial heterotrophic process, involved in the carbonate precipitation, was the ammonification of amino-acids ([Castanier et al., 1999] and [Castanier et al., 2000]).

The faecal pellets testify that two kinds of organisms lived in the depositional environment: deposit feeders (faecal pellets rich in terrigenous components) and suspension-feeders (faecal pellets with coccolithophorid remains). These oligotypic faecal pellets, which constitute the second component $(25 \%-35 \%)$ of the rock volume, together with the absence of skeletal metazoans, denote a relatively low community diversity, which can be explained by a rather unstable marine environment which underwent aperiodic freshwater inputs. Nonetheless, the presence of coccolithophorid moulds in the faecal pellets indicates that marine condition still survived, and the presence of bioturbation suggests that the $\mathrm{O} / \mathrm{R}$ boundary was situated below the water/sediment interface (Fig. 13a). However, random and short-lived dysoxic/suboxic episodes occurred at the sea floor (Fig. 13b). These are recorded by unbioturbated dark laminae and well preserved bright-fluorescent organic debris without any indication of degradation and oxidation.

The biological evidence in the microfacies (clotted peloidal micrite and faecal pellets), the very good preservation of primary microstructures and mineralogy, the absence of moulds and pseudomorphs after evaporitic minerals, all exclude evaporitic deposition of these sediments as well as diagenetic replacement of Ca-sulphates by carbonates. These considerations are confirmed by the absence of molecular fossils indicative of anoxic or hypersaline environment, such as pregnanes and homopregnanes, extended hopanes $\left(>\mathrm{C}_{33}\right)$, gammacerane and isorenieratane ([Moldowan et al., 1985], [ten Haven et al., 1985], [ten Haven et al., 1988], [Adam et al., 1993], [Schaeffer et al., 1995a], [Schaeffer et al., 1995b], [Sinninghe Damsté et al., 1995], [Kenig et al., 1995], [Gelin et al., 1995], [Keely et al., 1995] and [Schaeffer-Reiss et al., 1998]).

Finally, there is a slight upward increase in continental input in each carbonate bed, documented by the increases in OI, opaque terrestrial debris, and long chain $n$-alkyl lipids (fatty acids and $n$-alkanes with odd numbered chain).

\section{Conclusions}

The carbonate sediments of the Calcare di Base that preserve their original mineralogy (aragonite) and microstructures, have been studied from sedimentary, petrographic, geochemical and biochemical points of view.

The data allow us to put forward the following considerations: 
1. The dominant microfacies is constituted by peloidal micrite forming clots with antigravitative fabric. This microfacies can be explained as the consequence of the metabolic activity of micron sized organisms, which affected the depositional geometry of the peloids. This peloidal fabric together with the bacterial signal of the organic matter associated with these sediments could suggest microbially induced carbonate precipitation.

2. The noticeable and unusual amount of faecal pellets with uniform in morphology and size, together with the absence of skeletal metazoans, denotes an oligotypic marine community thriving in an unstable marine environment, characterized by aperiodic freshwater input. Zooclasts, referable to copepods, have been observed in the palynofacies, making it reasonable to attribute most of faecal pellets to these arthropods.

3. Rock-Eval pyrolysis revealed a transitional composition between Type II and Type III kerogen, suggesting a mixture of marine and terrigenous organic matter input. The molecular biogeochemical data indicate three main biological signatures: algae, bacteria and higher plants. These data point to a marine depositional scenario modified by conspicuous freshwater inputs.

4. The biological evidence in the microfacies, such as clotted peloidal micrites and faecal pellets, the very good preservation of the primary microstructure and mineralogy, and the absence of moulds and pseudomorphs after evaporitic minerals, make both evaporitic deposition of these sediments and diagenetic replacement of Ca-sulphates by carbonates, improbable. This is supported by coccolithophorid moulds in the faecal pellets, the low TOC and $\mathrm{S}$ content, dominant $\mathrm{C}_{27}$ steranes, and the absence of molecular fossils typical of evaporitic/anoxic environments.

5. Considering the presence of oxygen in the depositional environment, the freshwater inputs (with the consequent enrichment in organic matter and $\mathrm{Ca}^{2+}$ ions), the presumed absence of urea or uric acid (notably for the absence of vertebrates), and the very low amount of sulphates, it is reasonable to suppose that the main bacterial heterotrophic process involved in the precipitation of the Calcare di Base was the ammonification of amino-acids ([Castanier et al., 1999] and [Castanier et al., 2000]).

\section{Acknowledgements}

We wish to thank two anonymous reviewers for their constructive comments which greatly improved the manuscript. We are also indebted to Robert Riding (Cardiff University, U.K.) for helpful suggestions and English revision. Analytical and technical support were performed by Didier Keravis and Marielle Hatton (ISTO - Université d'Orléans, Bâtiment Géosciences, Orléans France). This research has been supported by grants MIUR (Project PRIN 2004 and ex $60 \%$ 2007, F. Russo). 


\section{References}

Adam et al., 1993 P. Adam, J.C. Schmid, B. Mycke, C. Strazielle, J. Connan, A. Huc, A. Riva and P. Albrecht, Structural investigation of non polar sulfur cross-linked macromolecules in petroleum, Geochim. Cosmochim. Acta 57 (1993), pp. 3395-3419.

Baranger and Disnar, 1988 P. Baranger and J.R. Disnar, Non-aromatic biomarkers associated with a Paleogene salt formation (Bresse, France), Org. Geochem. 13 (1988), pp. 647-653.

Baranger et al., 1989 P. Baranger, J.R. Disnar, G. Farjanel and P. Fourmont, Confrontation de données géochimiques et optiques quantitatives et qualitatives sur la matière organique associée aux séries salifères de Bresse, Bull. Soc. Géol. Fr. 8 (1989), pp. 967-978.

Bartle et al., 1979 K.D. Bartle, D.W. Jones, H. Pakdel, C.E. Snape, A. Calimli, A. Olcay and T. Tûgrl, Paraffinic hydrocarbons from supercritical gas extracts of coal as organic geochemical tracers, Nature 277 (1979), pp. 285-287.

Bellanca and Neri, 1986 A. Bellanca and R. Neri, Evaporite carbonate cycles of the Messinian, Sicily: Stable isotopes, mineralogy, textural features, and environmental implications, J. Sediment. Petrol. 56 (1986), pp. 614-621.

Bellanca et al., 2001 A. Bellanca, A. Caruso, G. Ferruzza, R. Neri, J.M. Rouchy, M. Sprovieri and M.M. Blanc-Valleron, Transition from marine to hypersaline condition in the Messinian Tripoli Formation from the marginal areas of the central Sicilian Basin, Sediment. Geol. 140 (2001), pp. 87-105.

Bonardi et al., 2001 G. Bonardi, W. Cavazza, V. Perrone and S. Rossi, Calabria-Peloritani terrane and northern Ionian Sea. In: G.B. Vai and I.P. Martini, Editors, Anatomy of an orogen: The Appenines and Adjacent Mediterranean Basins, Kluwer Academic Publishers (2001), pp. 287-306.

Bourdon et al., 2000 S. Bourdon, F. Laggoun-Défarge, O. Maman, J.-R. Disnar, B. Guillet, S. Derenne and C. Largeau, Organic matter sources and early diagenetic degradation in a tropical peaty marsh (Tritrivakely, Madagascar). Implications for environmental reconstruction during the Sub-Atlantic, Org. Geochem. 31 (2000), pp. 421-438.

Brassell et al., 1978 S.C. Brassell, G. Eglinton, J.R. Maxwell and R.P. Philp, Natural background of alkanes in the aquatic environment. In: O. Hutzinger, L.H. van Lelyveld and B.C.J. Zoeteman, Editors, Aquatic Pollutants: Transformation and Biological Effects, Pergamon Press, Oxford (1978), pp. 69-86.

Brassell et al., 1986 S.C. Brassell, G. Eglinton and F.J. Mo, Biological marker compounds as indicators of the depositional history of the Maoming oil shale, Org. Geochem. 10 (1986), pp. 927-941.

Buczynski and Chafetz, 1991 C. Buczynski and H.S. Chafetz, Habit of bacterially induced precipitates of calcium carbonate and the influence of medium viscosity on mineralogy, $J$. Sediment. Petrol. 61 (1991), pp. 226-233. 
Castanier et al., 1999 S. Castanier, G. Le Métayer-Levrel and J.-P. Perthuisot, Ca-carbonates precipitation and limestone genesis - the microbiogeologist point of view, Sediment. Geol. 126 (1999), pp. 9-23

Castanier et al., 2000 S. Castanier, G. Le Métayer-Levrel and J.-P. Perthuisot, Bacterial roles in the precipitation of carbonate minerals. In: R.E. Riding and S.M. Awramik, Editors, Microbial sediments, Springer Verlag, Berlin (2000), pp. 32-39.

Cavazza and De Celles, 1993 W. Cavazza and P.G. De Celles, Miocene submarine canyons and associated sedimentary facies in southeastern Calabria, southeastern Italy, Geol. Soc. Amer. Bull. 105 (1993), pp. 1297-1309.

Cavazza et al., 1997 W. Cavazza, J. Blenkinsop, P.G. De Celles, R.T. Patterson and E.G. Reinhardt, Stratigrafia e sedimentologia della sequenza sedimentaria oligocenico-quaternaria del bacino calabro-ionico, Boll. Soc. Geol. Ital. 116 (1997), pp. 51-77.

Chafetz, 1986 H.S. Chafetz, Marine peloids: a product of bacterially induced precipitation of calcite, J. Sediment. Petrol. 56 (1986), pp. 812-817.

Chaffee et al., 1986 A.L. Chaffee, D.S. Hoover, R.B. Johns and F.K. Schweighardt, Biological markers extractable from coal. In: R.B. Johns, Editor, Biological markers in the sedimentary record (1986).

Chuecas and Riley, 1969 L. Chuecas and J.P. Riley, Component fatty acids of the total lipids of some marine phytoplankton, J. Mar. Biol. Assoc. U.K. 49 (1969), pp. 97-116.

Connan et al., 1986 J. Connan, J. Bouroullec, D. Dessert and P. Albrecht, The microbial input in carbonate-anhydrite facies of a sabkha paleoenvironment from Guatemala: a molecular approach. In: D. Leythaeuser and J. Rullkötter, Editors, Advances in Organic Geochemistry, Pergamon Press, Oxford (1986), pp. 29-50.

Cranwell, 1982 P.A. Cranwell, Lipids of aquatic sediments and sedimenting particulates, Prog. Lipid Res. 21 (1982), pp. 271-308.

Critelli, 1999 S. Critelli, The interplay of lithospheric flexure and thrust accommodation in forming stratigraphic sequences in the southern Apennines foreland basin system, Italy, Rend. Lincei, Sci. Fis. Nat. 4 (1999), pp. 257-326.

Decima et al., 1988 A. Decima, J.A. McKenzie and B.C. Schreiber, The origin of "evaporitive" limestones: an example from the Messinian of Sicily (Italy), J. Sediment. Petrol. 58 (1988), pp. 256-272.

Dravis and Yurewicz, 1985 J.J. Dravis and D.A. Yurewicz, Enhanced carbonate petrography using fluorescence microscopy, J. Sediment. Petrol. 55 (1985), pp. 795-804.

Durand and Nicaiase, 1980 B. Durand and Nicaiase, Kerogen- insoluble organic matter from sedimentary rocks, Technip, Paris (1980).

Eglinton and Hamilton, 1967 G. Eglinton and R.J. Hamilton, Leaf epicuticular waxes, Science 156 (1967), pp. 1322-1335. 
Espitalié et al., 1977 J. Espitalié, M. Madec, B. Tissot and P. Leplat, Source rock characterization method for petroleum exploration, Proceedings of the Offshore Technology Conference, May 2-5, 1977, OTC, Houston, TX (1997), pp. 439-444.

Espitalié et al., 1985a J. Espitalié, G. Deroo and F. Marquis, La pyrolyse Rock-Eval et ses applications, Partie I, Rev. Inst. Fr. Pet. 40 (1985), pp. 563-579.

Espitalié et al., 1985b J. Espitalié, G. Deroo and F. Marquis, La pyrolyse Rock-Eval et ses applications, Partie II, Rev. Inst. Fr. Pet. 40 (1985), pp. 755-784.

Espitalié et al., 1986 J. Espitalié, G. Deroo and F. Marquis, La pyrolyse Rock-Eval et ses applications, Partie III, Rev. Inst. Fr. Pet. 41 (1986), pp. 73-89.

Folk and Chafetz, 2000 R.L. Folk and H.S. Chafetz, Bacterially induced microscale and nanoscale carbonate precipitates. In: R.E. Riding and S.M. Awramik, Editors, Microbial sediments, Springer Verlag, Berlin (2000), pp. 40-49.

Funiciello et al., 1997 R. Funiciello, M. Mattei, F. Speranza and C. Faccenna, La geodinamica del sistema Tirreno-Appennino, Le Scienze 343 (1997), pp. 44-53.

Gelin et al., 1995 F. Gelin, J.S. Sinninghe Damsté, W.N. Harrson, J. Maxwell and J.W. De Leeuw, Molecular indicators for palaeoenvironmental change in a Messinian evaporitic sequence (Vena del Gesso, Italy): III. Stratigraphic changes in the molecular structure of kerogen in a single marl bed as revealed by flash pyrolysis, Org. Geochem. 23 (1995), pp. $555-566$.

Grice et al., 1998 K. Grice, S. Schouten, K.E. Peters and J.J. Sinninghe Damsté, Molecular isotopic characterisation of hydrocarbon biomarkers in Palaeocene-Eocene evaporitic, lacustrine source rocks from the Jianghan Basin, China, Org. Geochem. 29 (1998), pp. 17451764.

Grimalt and Albaigés, 1990 J.O. Grimalt and J. Albaiges, Characterization of the depositional environments of the Ebro Delta (western Mediterranean) by the study of sedimentary lipid markers, Mar. Geol. 95 (1990), p. 207224.

Grimalt et al., 1992 J.O. Grimalt, R. de Wit, P. Teixidor and J. Albaiges, Lipid biogeochemistry of Phormidium and Microcoleus mats, Org. Geochem. 26 (1992), pp. 509530 .

Kazmierczak et al., 1996 J. Kazmierczak, M.L. Coleman, M. Gruszczynski and S. Kempe, Cyanobacterial key to the genesis of micritic and peloidal limestones in ancient seas, Acta Palaeontol. Pol. 41 (1996), pp. 319-338.

Keely et al., 1995 B.J. Keely, S.R. Blake, P. Schaeffer and J.R. Maxwell, Distributions of pigments in the organic matter of marls from the Vena del Gesso evaporitic sequence, Org. Geochem. 23 (1995), pp. 527-539.

Kenig et al., 1995 F. Kenig, J.S. Sinninghe Damsté, N.L. Frewin, J.M. Hayes and J.W. De Leeuw, Molecular indicator for palaeoenvironmental change in a Messinian evaporitic sequence (Vena del Gesso, Italy). II: high-resolution variations in abundances and 13C 
contents of free and sulphur-bound carbon skeletons in a single marl bed, Org. Geochem. 23 (1995), pp. 485-526.

Krijgsman et al., 1999a W. Krijgsman, F.J. Hilgen, S. Marabini and G.B. Vai, New paleomagnetic and cyclostratigraphic age constraints on the Messinian of the Northern Apennines (Vena del Gesso Basin, Italy), Mem. Soc. Geol. Ital. 54 (1999), pp. 25-33.

Krijgsman et al., 1999b Krijgsman, W., Hilgen, F.J., Raffi, I., Sierro, F.J., Wilson, D.S., 1999b. Cronology, causes and progression of the Messinian salinity crisis. Letters to nature, Nature Ref. N9414L (PHYS).

Lafargue et al., 1998 E. Lafargue, F. Marquis and D. Pillot, Rock-Eval 6 applications in hydrocarbon exploration, production, and soil contamination studies, Oil Gas Sci. Technol. 53 (1998), pp. 421-437.

Machel et al., 1991 H.G. Machel, R.A. Mason, A.N. Mariano and A. Mucci, Causes and emission of luminescence in calcite and dolomite. In: C.E. Barker and O.C. Koop, Editors, Luminescence Microscopy and Spectroscopy: Qualitative and Quantitative Applications. SEMP Short Course vol. 25 (1991), pp. 9-25.

Mackenzie et al., 1980 A.S. Mackenzie, R.L. Patience and J.R. Maxwell, Molecular parameters of maturation in the Toarcian shales, Paris Basin, France; I, Changes in the configuration of acyclic isoprenoid alkanes, steranes and triterpanes, Geochim. Cosmochim. Acta 44 (1980), pp. 1709-1722.

Malinverno and Ryan, 1986 A. Malinverno and W.B.F. Ryan, Extension in Tyrrhenian sea and shortening in the Appennines as result of arc migration driven by sinking of the lithosphere, Tectonics 5 (1986), pp. 227-254.

Mattei et al., 2002 M. Mattei, P. Cipollati, D. Casentino, A. Argentieri, F. Rossetti, F. Speranza and L. Di Bella, The Miocene tectono-sedimentary evolution of the Southern Tyrrhenian Sea: stratigraphy, structural and paleomagnetic data from the on-shore Amantea basin (Calabrian arc, Italy), Basin Res. 14 (2002), pp. 147-168.

McKenzie, 1985 J.A. McKenzie, Stable-isotope mapping in Messinian evaporative carbonates of central Sicily, Geology 13 (1985), pp. 851-854.

Moldowan et al., 1985 J.M. Moldowan, W.K. Seifert, E. Arnold and J. Clardy, Relationship between petroleum composition and depositional environment of petroleum source rocks, $\mathrm{Am}$. Assoc. Pet. Geol. Bull. 69 (1985), pp. 1255-1268.

Neuweiler and Reitner, 1995 Neuweiler, F., Reitner, J., 1995. Epifluorescence-microscopy of selected automicrites from lower Carnian Cipit-boulders of the Cassian formation (Seeland Alpe, Dolomites). In: Reitner, J. and Neuweiler, F. (coordinators). Mud Mounds: a polygenetic spectrum of fine-grained carbonate buildups. Facies 32, 26-28.

Ogniben, 1957 L. Ogniben, Petrografia della serie solfifera Siciliana e considerazioni geologiche relative, Mem. Descr. Carta Geol. Ital. 8 (1957), pp. 453-763. 
Ogniben, 1963 L. Ogniben, Sedimenti Halitico-Calcitici a struttura grumosa nel Calcare di Base Messiniano in Sicilia, G. Geol. 2 (1963), pp. 509-542.

Ourisson et al., 1987 G. Ourisson, M. Rohmer and K. Porolla, Prokaryotic hopanoids and othe polyterpenoid sterol surrogates, Annu. Rev. Microbiol. 41 (1987), pp. 301-333.

Patacca and Scandone, 1989 E. Patacca and P. Scandone, Post-Tortonian mountain building in the Apennines. the role of the passive sinking of a relict lithospheric slab. In: A. Boriani, M. Bonafede, G.B. Piccardo and G.B. Vai, Editors, The lithosphere in Italy: Advances in Earth Science Research vol. 80, Accademia Nazionale dei Lincei (1989), pp. 157-176.

Patacca et al., 1990 E. Patacca, R. Sartori and P. Scandone, Tyrrhenian basin and Appenninic arcs: kinematic relations since late Tortonian times, Mem. Soc. Geol. Ital. 45 (1990), pp. 425 451.

Pedley and Grasso, 1993 H.M. Pedley and M. Grasso, Controls on faunal and sediment cyclicity within the Tripoli and Calcare di Base basin (Late Miocene) of central Sicily, Palaeogeogr. Palaeoclimatol. Palaeoecol. 105 (1993), pp. 337-360.

Peters et al., 2005 K.E. Peters, C.C. Walters and J.M. Moldowan, The Biomarker Guide (Second Edition), Cambridge University Press (2005), p. 1155.

Roda, 1964 C. Roda, Distribuzione e facies dei sedimenti neogenici del Bacino di Crotonese, Geol. Rom. 3 (1964), pp. 319-366.

Rosa-Putra et al., 2001 S. Rosa-Putra, R. Nalin, A.-M. Domenach and M. Rohmer, Novel hopanoids from Frankia spp. and related soil bacteria: squalene cyclization and significance of geological biomarkers revisited, Eur. J. Biochem. 268 (2001), pp. 4300-4306.

Rouchy and Saint-Martin, 1992 J.M. Rouchy and J.P. Saint-Martin, Late Miocene events in the Mediterranean as recorded by carbonate-evaporite relations, Geology 20 (1992), pp. 629632.

Rouchy and Caruso, 2006 J.M. Rouchy and A. Caruso, The Messinian salinity crisis in the Mediterranean basin: a reassessment of the data and an integrated scenario, Sediment. Geol. 188-189 (2006), pp. 35-67.

Russell et al., 1997 M. Russell, J.O. Grimalt, C. Taberner and J.M. Rouchy, Bacterial and algal inputs in sedimentary organic matter deposited under natural sulphurization conditions (Lorca Basin, Murcia, Spain), Org. Geochem. 26 (1997), pp. 605-625.

Russo et al., 1997 F. Russo, C. Neri, A. Mastandrea and A. Baracca, The mud-mound nature of the Cassian platform margins of the Dolomites. A case history: the Cipit Boulders from Punta Grohmann (Sasso Piatto Massif, Northern Italy), Facies 36 (1997), pp. 25-36.

Sartori, 1990 R. Sartori, The main results of ODP Leg 107 in the frame of Neogene to recent geology of the peri-Tyrrenian areas. In: K.A.M. J. Kastens, Editor, Ocean Drilling Program, Scientific Results vol. 107 (1990), pp. 715-730. 
Schaeffer et al., 1995a P. Schaeffer, C. Reiss and P. Albrecht, Geochemical study of macromolecular organic matter from sulfur-rich sediments of evaporitic origin (Messinian of Sicily) by chemical degradations, Org. Geochem. 23 (1995), pp. 567-581.

Schaeffer et al., 1995b P. Schaeffer, W.N. Harrison, B.J. Keely and J.R. Maxwell, Product distributions from chemical degradation of kerogens from a marl from a Miocene evaporitic sequence (Vena del Gesso, N. Italy), Org. Geochem. 23 (1995), pp. 541-554.

Schaeffer-Reiss et al., 1998 C. Schaeffer-Reiss, P. Schaeffer, A. Putschew and J.R. Maxwell, Stepwise chemical degradation of immature S-rich kerogens from Vena del Gesso (Italy), Org. Geochem. 29 (1998), pp. 1857-1873.

Sebag et al., 2006 D. Sebag, S. Ogier, V. Mesnage, C. Di Giovanni, F. Laggoun-Défarge and A. Durand, Inventory of sedimentary organic matter in modern wetland (Marais Vernier, Normandy, France) as source-indicative tools to study Holocene alluvial deposits (Lower Seine Valley, France), Int. J. Coal Geol. 67 (2006), pp. 1-16.

Seifert and Moldovan, 1980 W.K. Seifert and J.M. Moldovan, The effect of thermal stress on source-rock quality as measured by hopane stereochemistry. In: J.R. Maxwell, Editor, Physics and Chemistry of the Earth, Pergamon, Oxford (1980), pp. 229-237.

Sinninghe Damsté et al., 1995 J.S. Sinninghe Damsté, N.L. Frewin, F. Kenig and J.W. De Leeuw, Molecular indicators for palaeoenvironmental change in a Messinian evaporitic sequence (Vena del Cesso, Italy). I: variations in extractable organic matter of ten cyclically deposited marl beds, Org. Geochem. 23 (1995), pp. 471-483.

Summons, 1993 R.E. Summons, Biogeochemical cycles: a review of fundamental aspects of organic matter formation, preservation and composition. In: S.A. Macko, Editor, Organic Geochemistry Principles and Applications, Plenum, New York (1993), pp. 3-21.

Tamajo, 1961 E. Tamajo, Probabili tracce di vita in livelli ritenuti azoici della formazione solfifera siciliana, Riv. Min. Sicil. 67 (1961), pp. 3-11.

ten Haven et al., 1985 H.L. ten Haven, J.W. de Leeuw and P.A. Schenck, Organic geochemical studies of a Messinian evaporitic basin, northern Apennines (Italy) I: hydrocarbon biological markers for a hypersaline environment, Geochim. Cosmochim. Acta 49 (1985), pp. 2181-2191.

ten Haven et al., 1988 H.L. ten Haven, J.W. de Leeuw, J.S. Sinninghe Damste, P.A. Schenck, S.E. Palmer and J.E. Zumberge, Application of biological markers in the recognition of palaeohypersaline environments. In: A.J. Fleet et al., Editors, Lacustrine Petroleum Sourcerocks. Geological Society Special Publication vol. 40, Blackwell Scientific Publications, Oxford (1988), pp. 123-130.

Thiel et al., 1997 V. Thiel, M. Merz-Preiß, J. Reitner and W. Michaelis, Biomarker studies on microbial carbonates: extractable lipids of a calcifying cyanobacterial mat (Everglades, USA), Facies 36 (1997), pp. 163-172.

Thiel et al., 2003 V. Thiel, M. Blumenberg, T. Pape, R. Seifert and M. Michaelis, Unexpected occurrence of hopanoids at gas seeps in the Black Sea, Org. Geochem. 34 (2003), pp. 81-87. 
Tissot and Welte, 1984 Tissot, B.P., Welte, D.H., 1984. Petroleum formation and occurrence. Second revised and enlarged edition. Springer-Verlag, Berlin, Heidelberg, New York, Tokyo, pp.699.

Van Dijk et al., 2000 J.P. Van Dijk, M. Bello, G.P. Brancaleoni, G. Cantarella, V. Costa, A. Frixa, F. Golfetto, S. Merlini, M. Riva, S. Torricelli, C. Toscano and A. Zerilli, A regional structural model for the northern sector of the Calabrian Arc (southern Italy), Tectonophysics 324 (2000), pp. 267-320.

Volkman, 1986 J.K. Volkman, Review of sterol markers for marine and terrigenous organic matter, Org. Geochem. 9 (1986), pp. 83-99.

Volkman et al., 1980a J.K. Volkman, R.B. Johns, F.T. Gillan, G.J. Perry and H.J. Bavor, Microbial sediments of an intertidal sediment - I. Fatty acids and hydrocarbons, Geochim. Cosmochim. Acta 44 (1980), pp. 1133-1143.

Volkman et al., 1980b J.K. Volkman, G. Eglinton and E.D.S. Corner, Sterols and fatty acids of the marine diatom Biddulphia sinensis, Phytochemistry 19 (1980), pp. 1809-1813.

Wolff et al., 1986 G.A. Wolff, N.A. Lamb and J.R. Maxwell, The origin and fate of 4-methyl steroids - II. Dehydration of stanols and occurrence of $\mathrm{C}_{30}$ 4-methyl steranes, Org. Geochem. 10 (1986), pp. 965-974.

Zecchin et al., 2004 M. Zecchin, F. Massari, D. Mellere and G. Prosser, Anatomy and evolution of a Mediterranean-type fault bounded basin: the lower Pliocene of the northern Crotone basin (southern Italy), Basin Res. 16 (2004), pp. 117-143. 


\section{Figures}

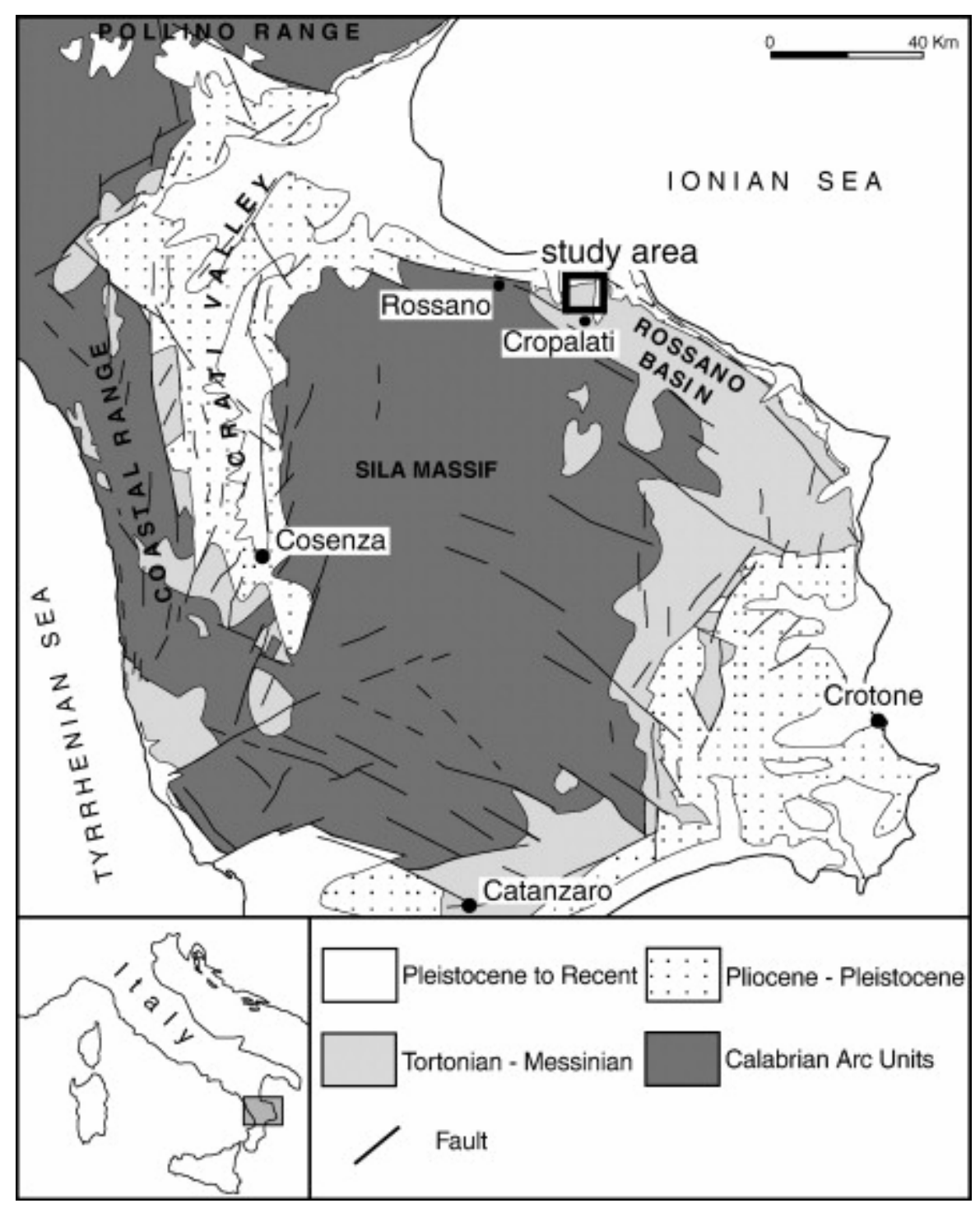

Fig. 1. Simplified geological map of northern Calabria and the location of the study area. 


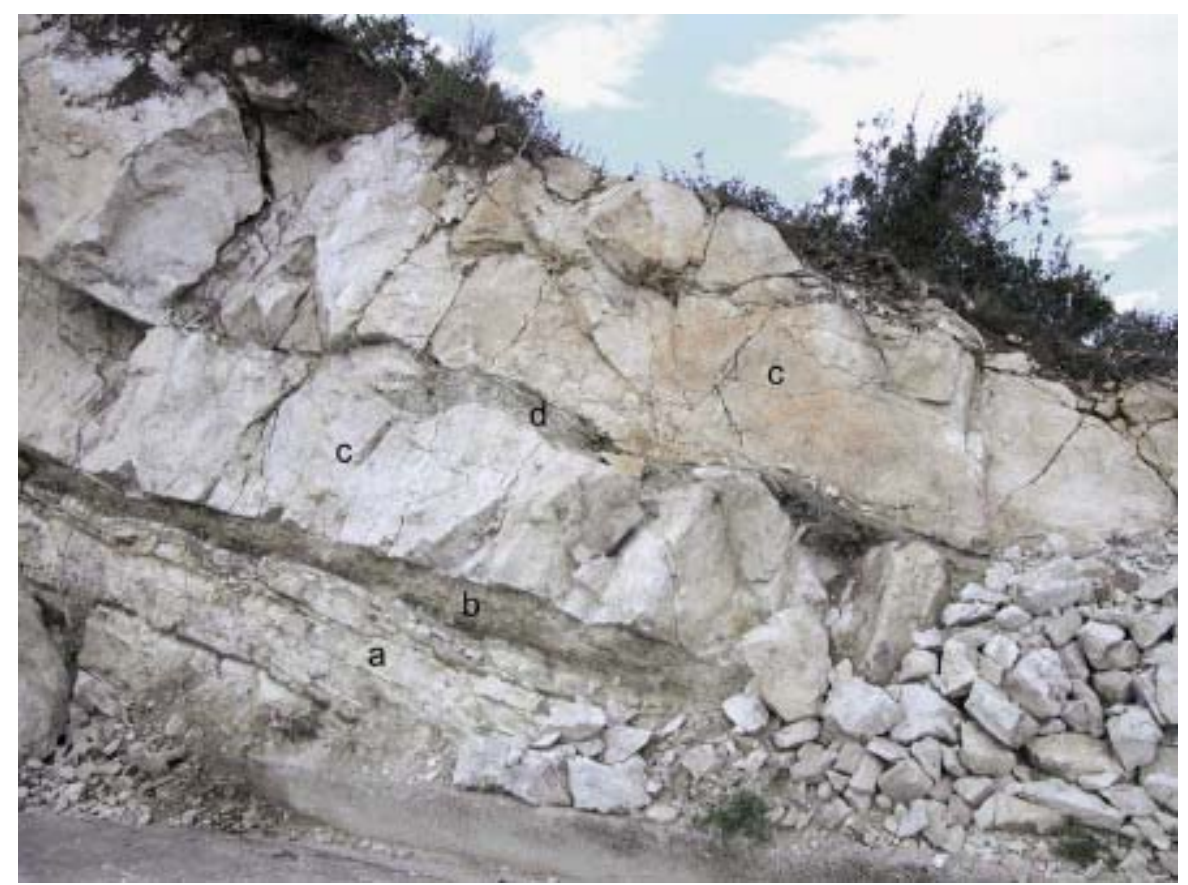

Fig. 2. General view of the study section showing the (a) diatomites and (b) marls of the Tripoli Formation and (c) carbonate beds and (d) marl of the Calcare di Base Formation. 


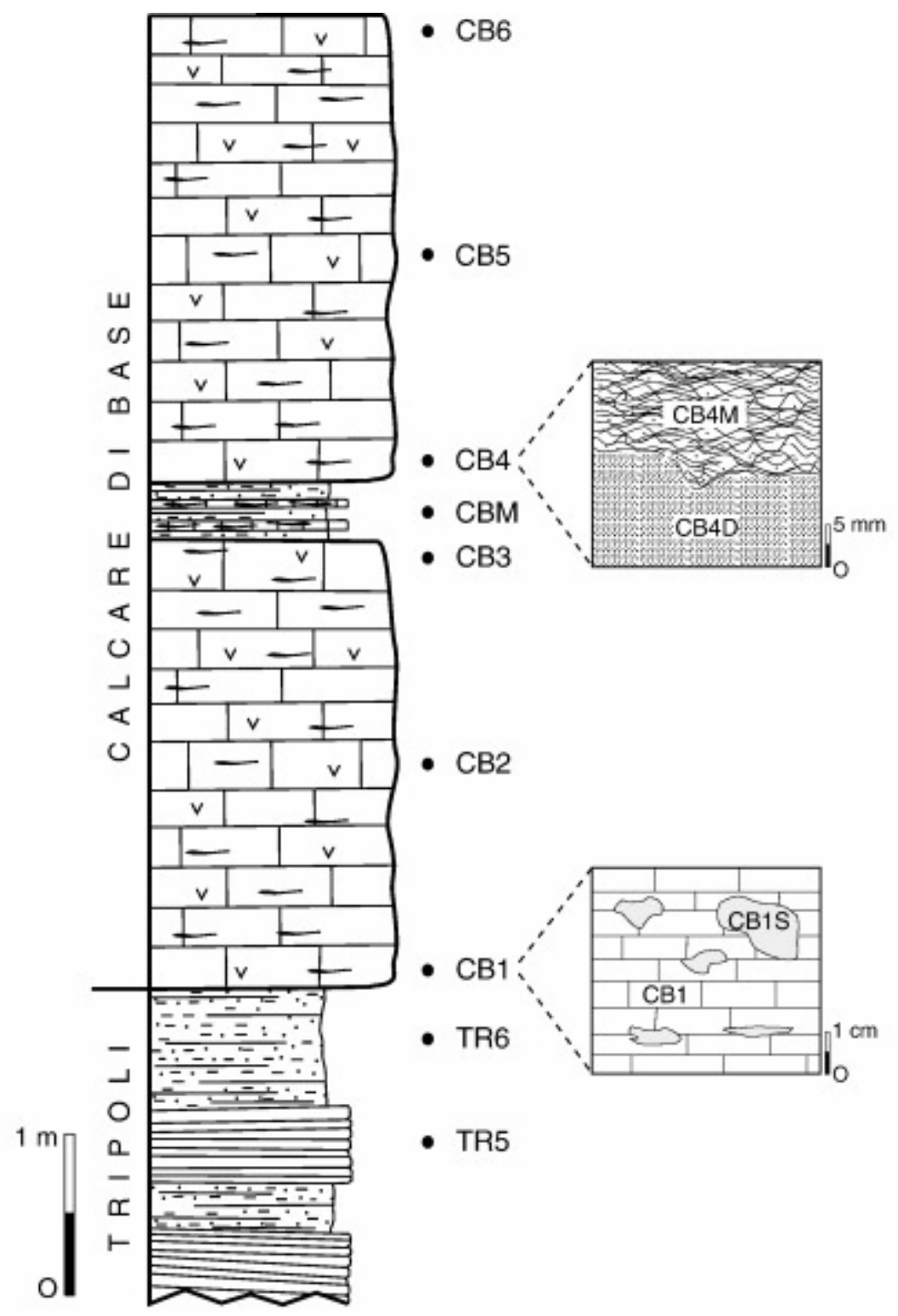

CALCARE DI BASE

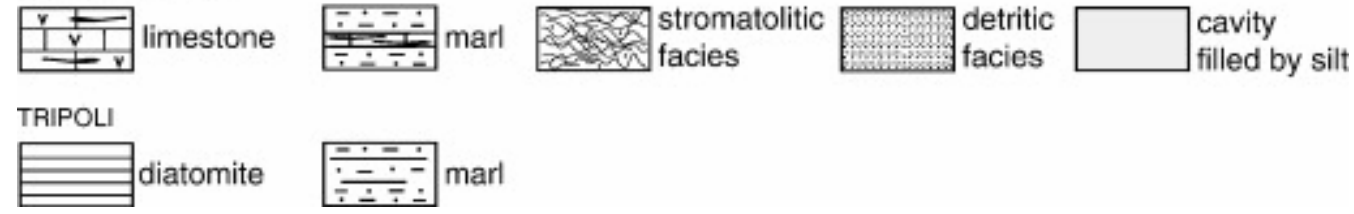

Fig. 3. Stratigraphic column of the Cropalati section with the location of the samples. 

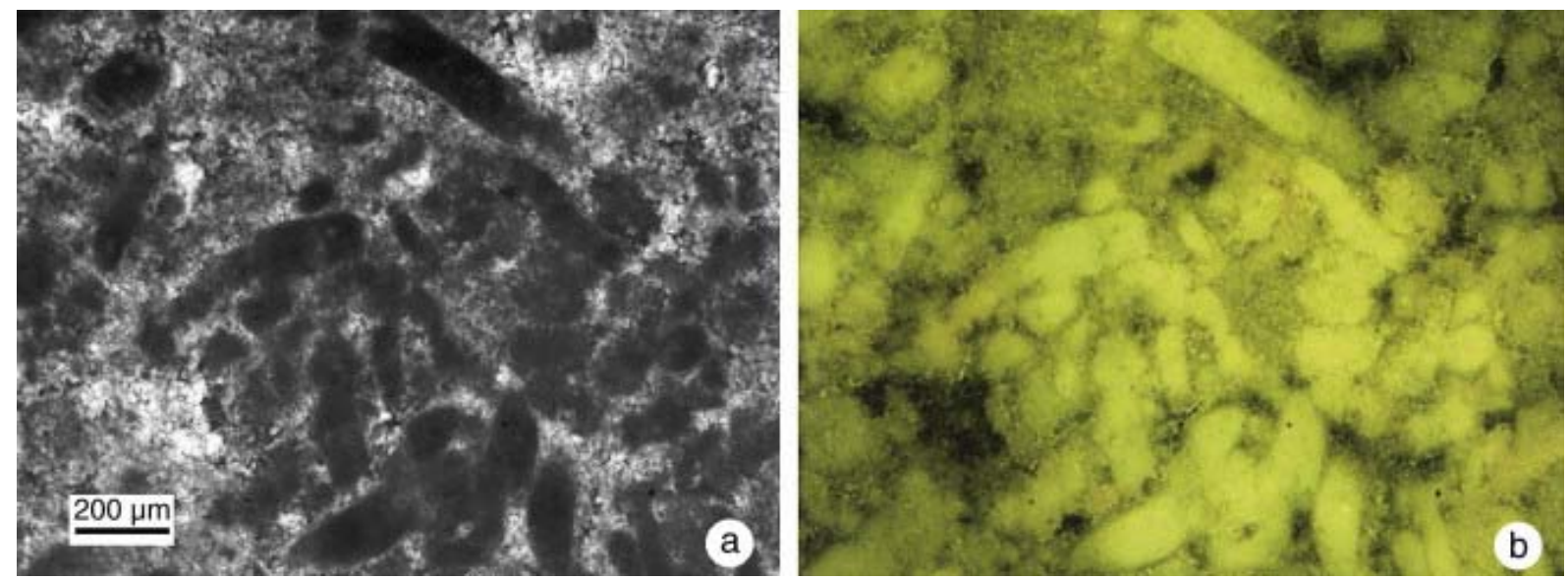

Fig. 4. Transmitted light photomicrographs of peloidal (coprolitic) microfacies: (a) transmitted light; (b) epifluorescence UV (thin section of the sample CB3).

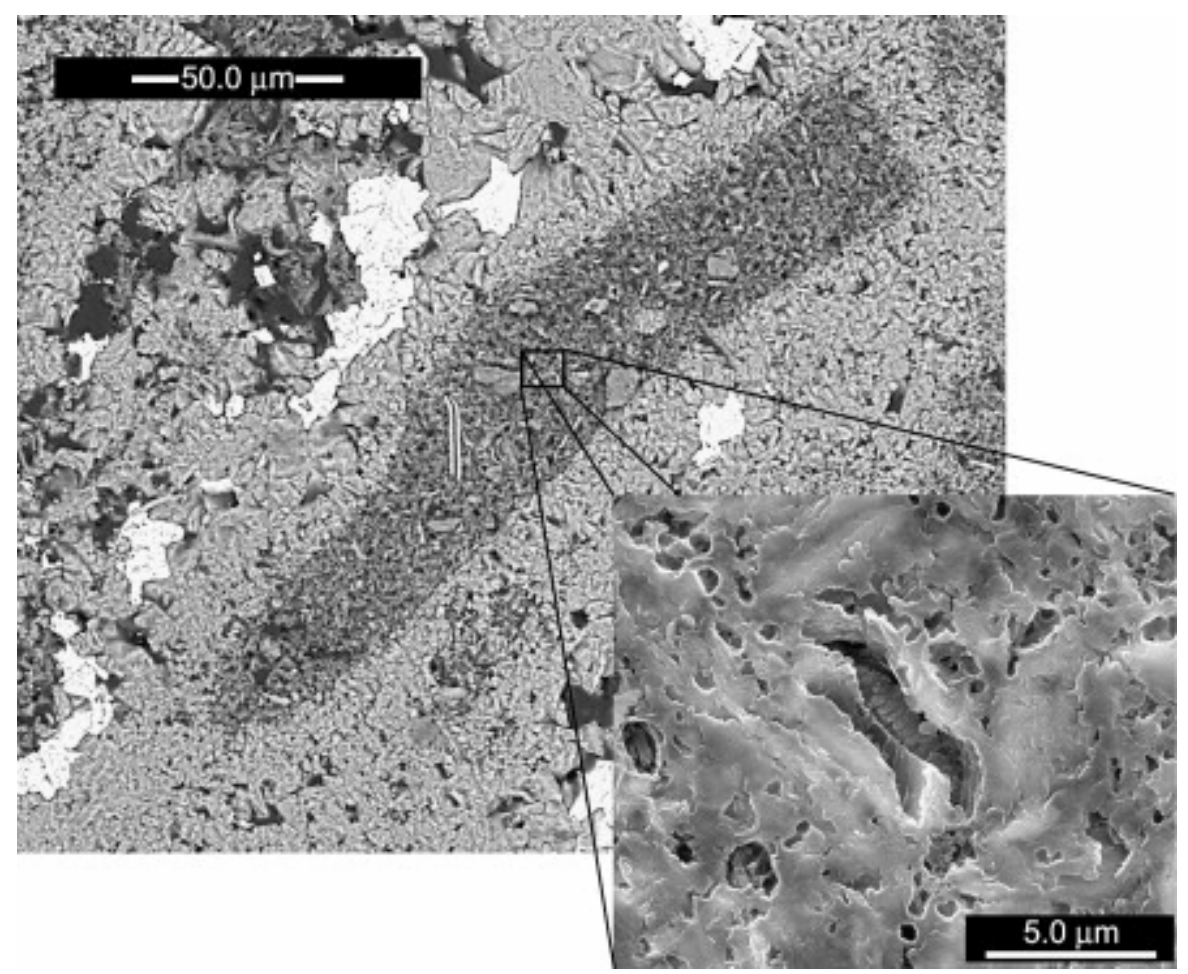

Fig. 5. SEM image of a polished and etched ( $\mathrm{HCl} 0.1 \%$ ) thin section (sample $\mathrm{CB} 1$ ) showing a coprolite longitudinal section in which it is possible to observe a coccolithophorid mould. 


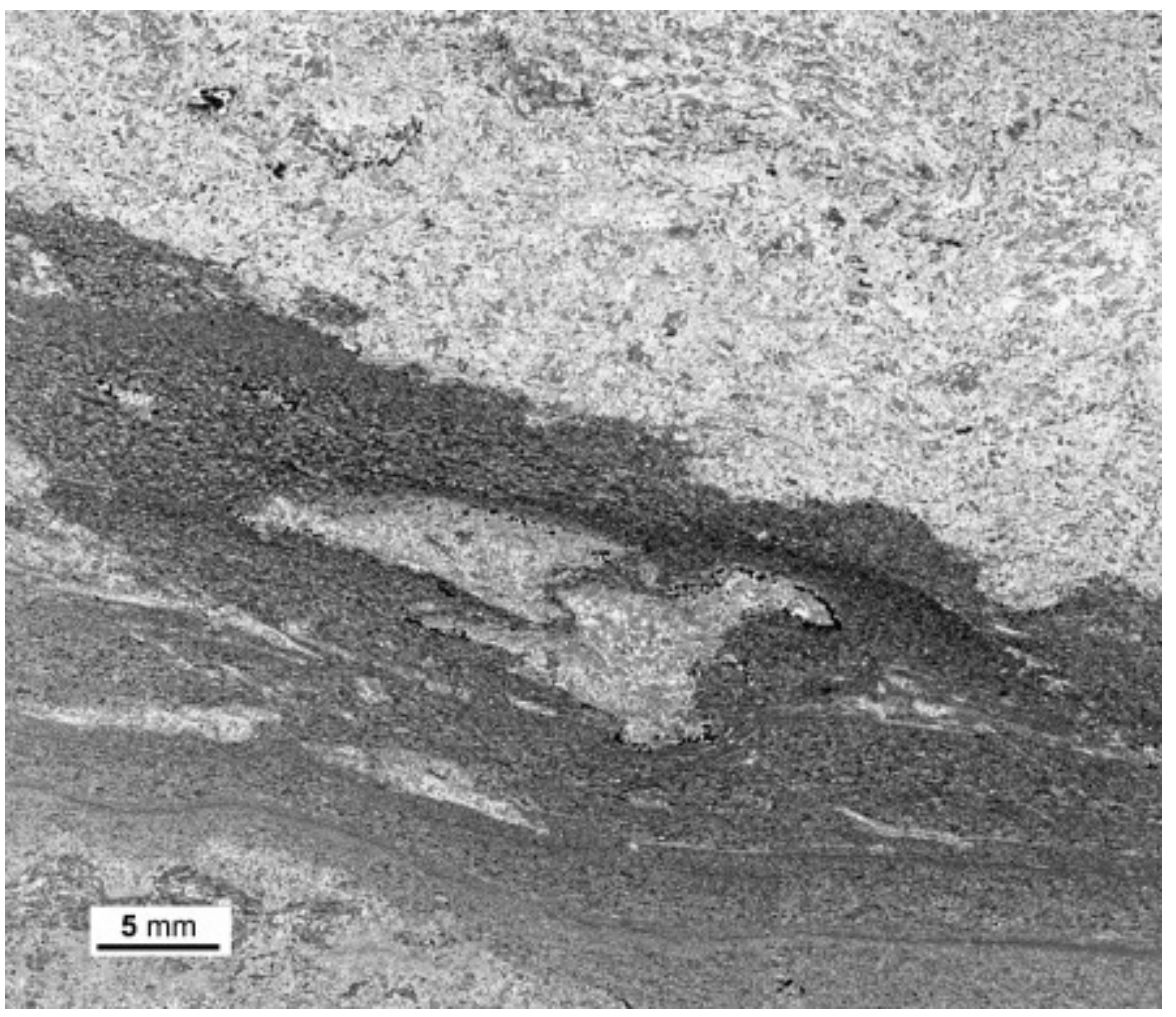

Fig. 6. Transmitted light photomicrograph of the burrowed detritic microfacies (thin section of the sample CB1).
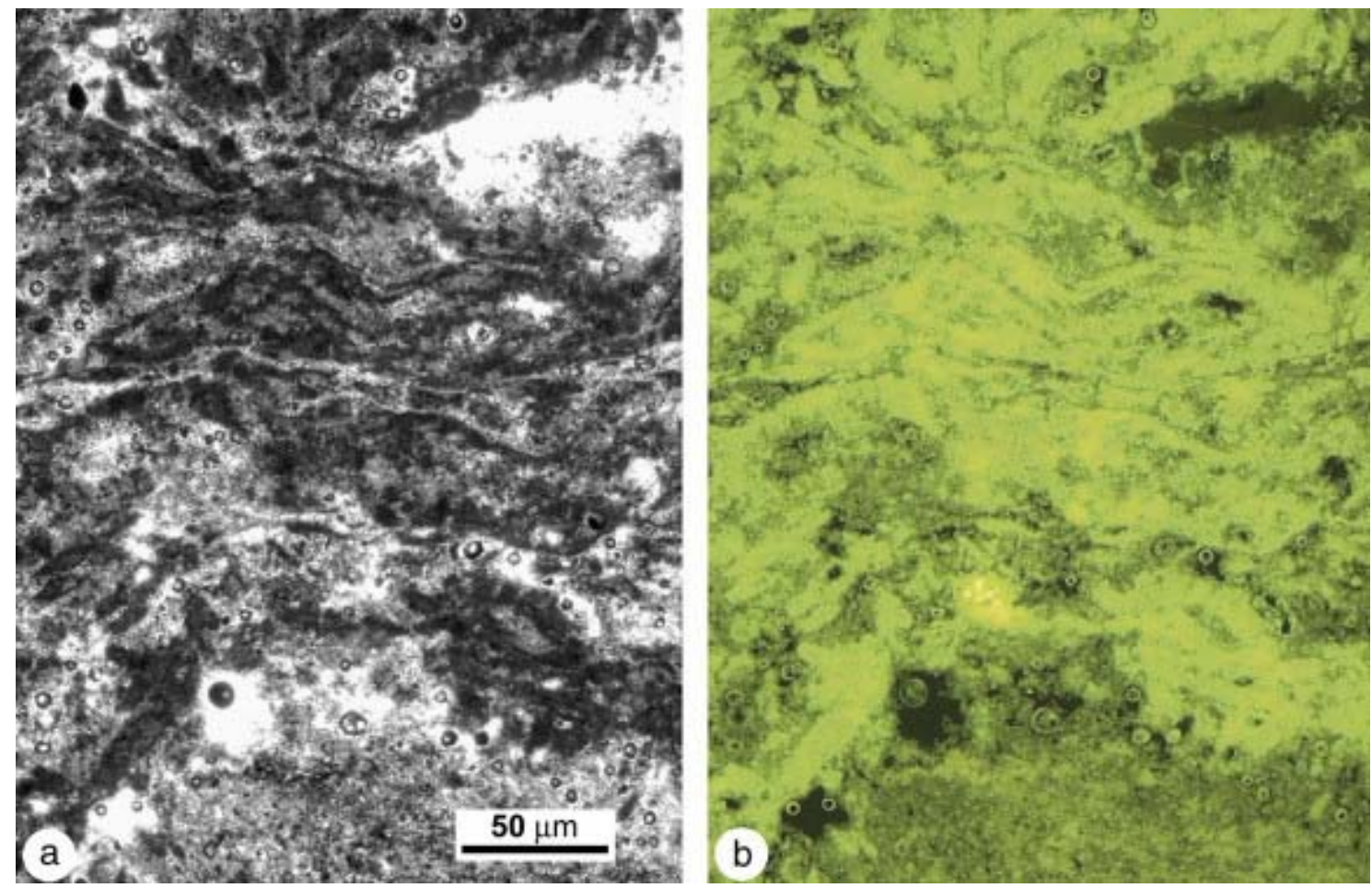

Fig. 7. Thin section photomicrographs of the sample CB5. (a) Transmitted light; (b) Epifluorescence UV, showing the dark and light thin laminae of stromatolitic microbioalite microfacies. 

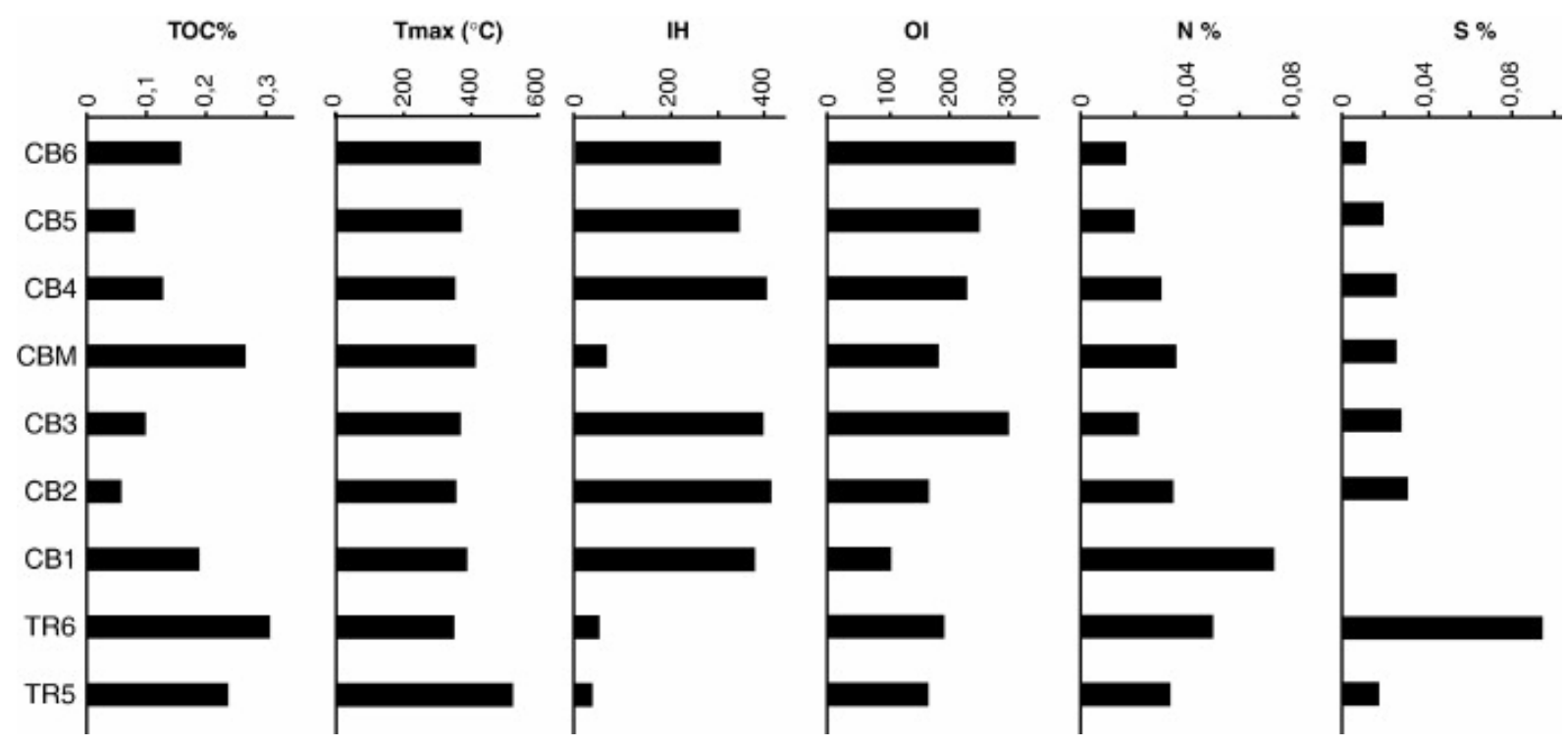

Fig. 8. Histograms showing total organic carbon (TOC), Tmax, hydrogen index (HI), oxygen index $(\mathrm{OI})$, total nitrogen content $(\mathrm{N})$ and total sulphur content $(\mathrm{S})$.

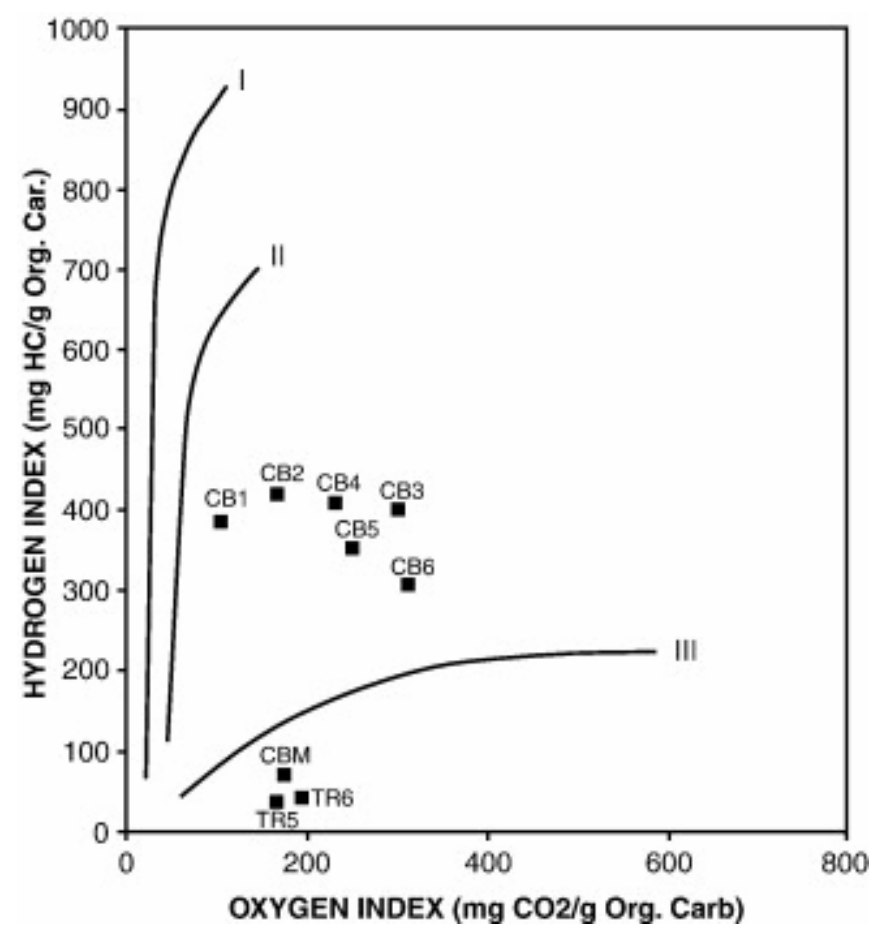

Fig. 9. Oxygen and hydrogen indices of the samples from Tripoli Formation (TR) and Calcare di Base Formation (CB) plotted on a modified van Krevelen diagram. 


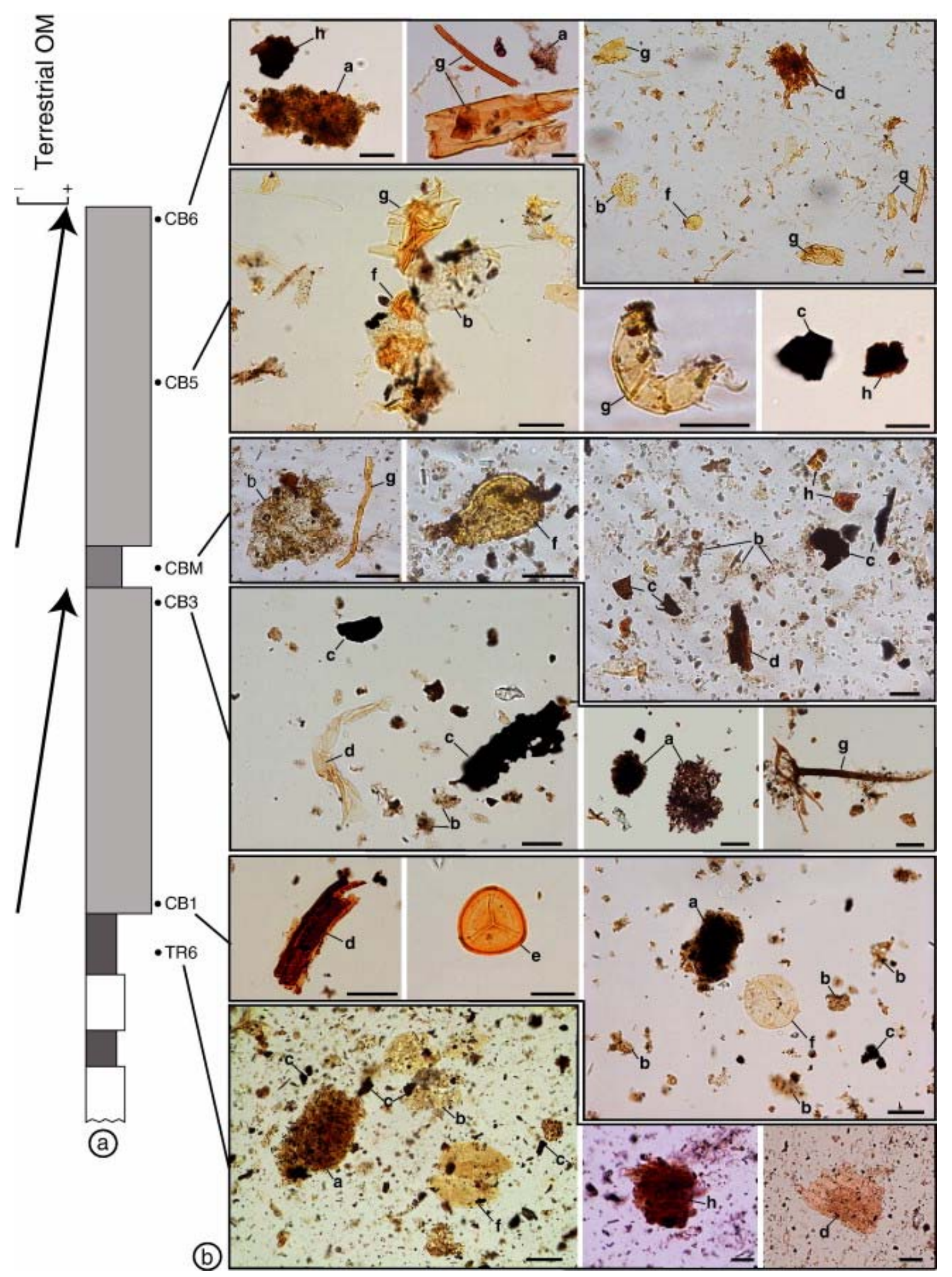

Fig. 10. (A) Stratigraphic column with the position of the selected samples. (B) Main palynofacies distribution of the analysed samples. Only the palynofacies rich in organic micro-remains are illustrated. (a) Altered amorphous OM (AOM); (b) preserved (AOM); (c) oxidized or burnt terrestrial debris; (d) plant-derived ligno-cellulosic tissues; (e) spores and pollen grains; (f) phytoplanktonic organisms; (g) epiderm and appendix of arthropod; (h) gelified terrestrial debris; (scale bars $20 \mu \mathrm{m}$ ). 

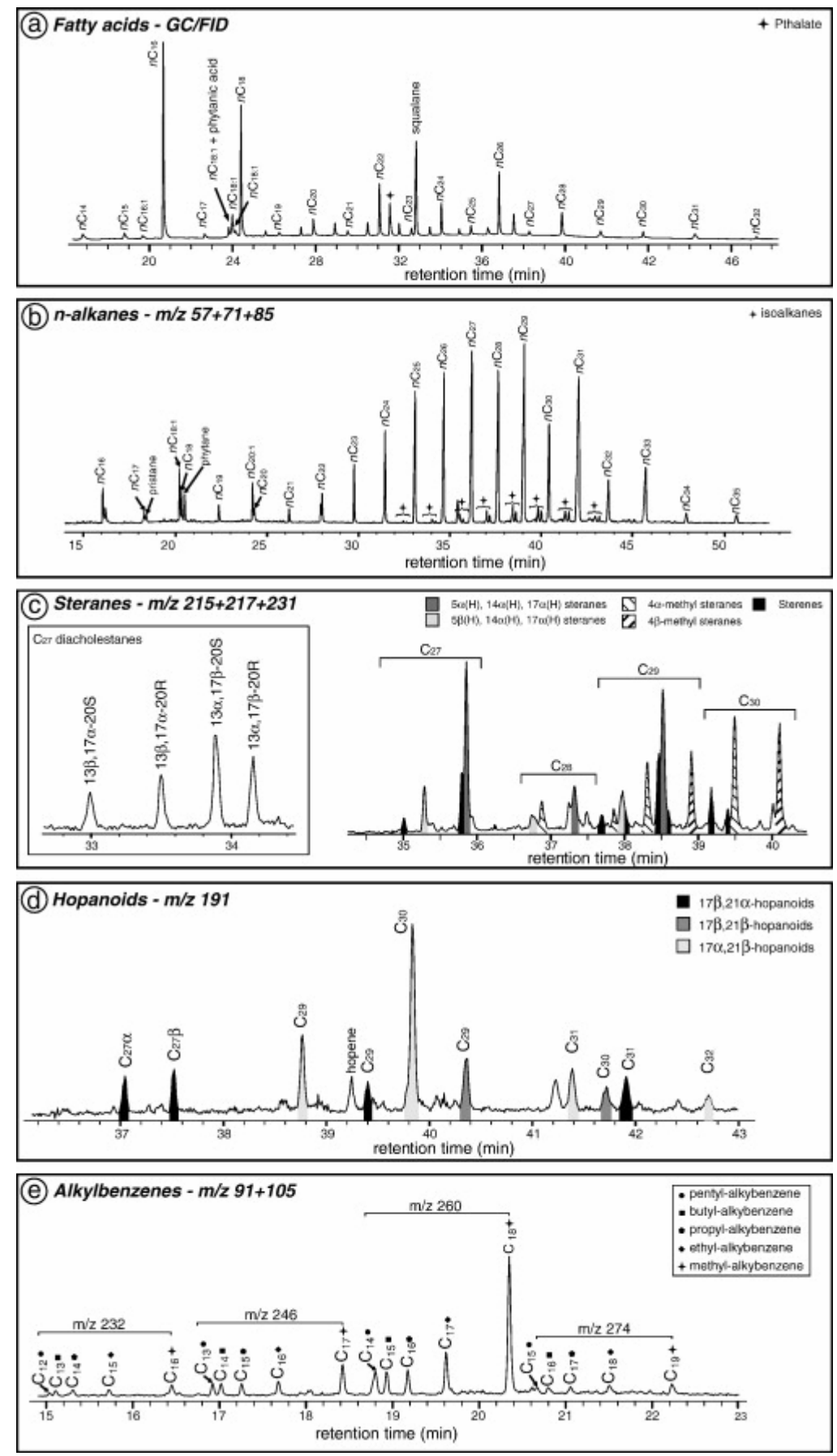

Fig. 11. Example of biomarker distributions in the fatty acid and hydrocarbon fractions: (a) partial gas chromatogram (GC/FID) of the acidic fraction for sample TR5 showing the distribution of fatty acids; (b) partial $m / z 57+71+85$ (GC/MS) mass fragmentogram of the hydrocarbon fraction of sample TR5 showing the distribution of $n$-alkanes, iso-alkanes and isoprenoid hydrocarbons; (c) partial $\mathrm{m} / z 215+217+231$ mass fragmentogram (GC/MS) of the hydrocarbon fraction illustrating the distribution of steranes in sample CBM. The distribution of $\mathrm{C}_{27}$ diacholestane isomers in sample $\mathrm{CB} 1$ is illustrated in a separate window on the $\mathrm{m} / \mathrm{z} 215+217+231$ mass fragmentogram; (d) partial $\mathrm{m} / \mathrm{z} 191$ mass fragmentogram (GC/MS) of the hydrocarbon fraction illustrating the distribution of hopanoids in sample TR5; (e) partial $\mathrm{m} / \mathrm{z} 91+105$ mass fragmentogram (GC/MS) of the hydrocarbon fraction illustrating the distribution of alkylbenzenes in sample CB4M. 


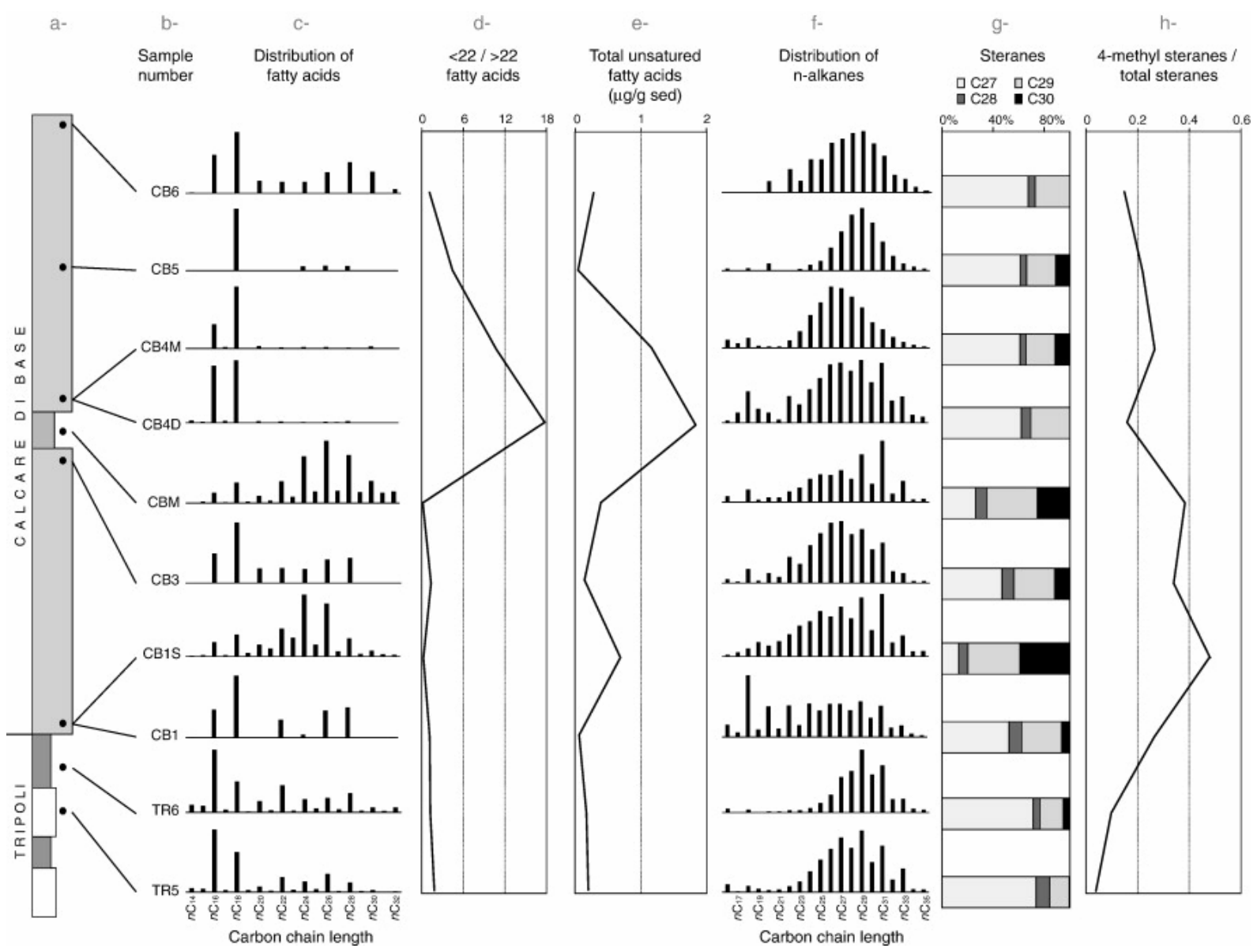

Fig. 12. Evolution of biomarkers through the section: (a) stratigraphic column with the position of the samples; (b) sample number; (c) distributions of linear fatty acids; (d) evolution of the ratio between short chain $(<\mathrm{C} 22)$ and long chain $(>\mathrm{C} 22)$ linear fatty acids; (e) evolution of the abundance of unsaturated fatty-acids; (f) distributions of $n$-alkanes; ( $\mathrm{g}$ ) relative proportions of steranes; (h) evolution of the ration between 4-methyl steranes and total steranes. 


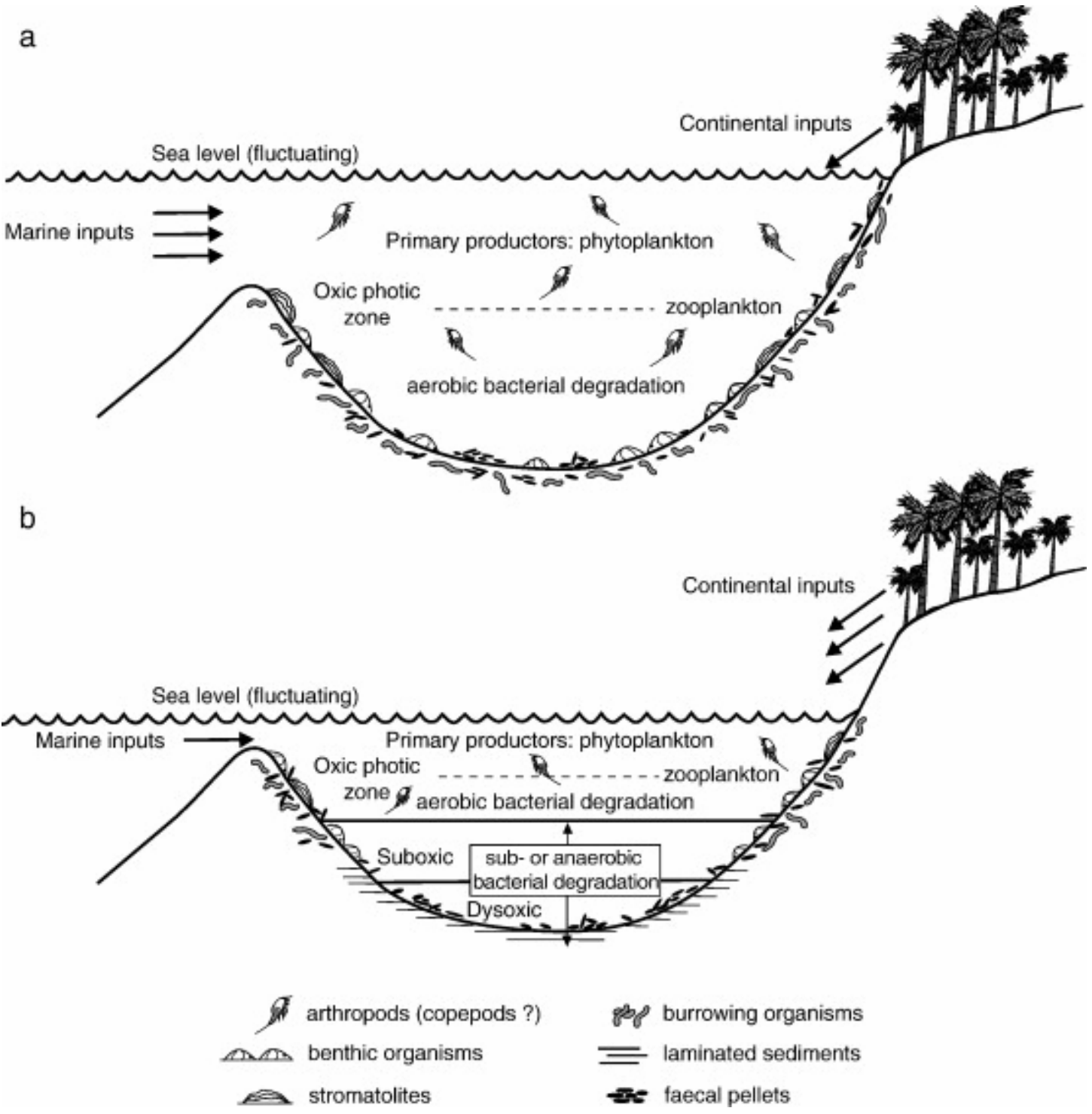

Fig. 13. Schematic palaeoecological reconstructions of depositional environments of the Calcare di Base in the Rossano Basin. (a) Oxic and (b) suboxic/dysoxic conditions of the lower water mass. 